\title{
O ESTADO ECONÔMICO DE EMERGÊNCIA E AS TRANSFORMAÇÕES DO DIREITO FINANCEIRO BRASILEIRO
}

\begin{abstract}
Tese de Doutorado, apresentada à Banca Examinadora do Programa de Pós-Graduação em Direito da Faculdade de Direito da Universidade de São Paulo, como exigência parcial para obtenção do título de Doutor em Direito, na área de concentração Direito Econômico, Financeiro e Tributário, sob a orientação da Prof. Dr. Fernando Facury Scaff e sob a coorientação da Prof ${ }^{a}$ Violeta Ruiz Almendral.
\end{abstract}

UNIVERSIDADE DE SÃO PAULO

FACULDADE DE DIREITO

São Paulo 
Catalogação da Publicação

Serviço de Biblioteca e Documentação

Faculdade de Direito da Universidade de São Paulo

Silveira, Francisco Secaf Alves

O estado econômico de emergência e as transformações do Direito Financeiro brasileiro / Francisco Secaf Alves Silveira ; orientador Fernando Facury Scaff -- São Paulo, 2018.

295

Tese (Doutorado - Programa de Pós-Graduação em Direito Direito Econômico, Financeiro e Tributário) - Faculdade de Direito, Universidade de São Paulo, 2018.

1. Direito Financeiro. 2. Constituição. 3. Finanças Públicas. I. Scaff, Fernando Facury, orient. II. Título. 
SILVEIRA, Francisco Secaf Alves

O estado econômico de emergência e as transformações do Direito Financeiro brasileiro

Tese apresentada à Faculdade de Direito da Universidade de São Paulo como exigência parcial para obtenção do título de Doutor em Direito.

Aprovado em:

Banca Examinadora

Prof. Dr. Instituição:

Julgamento: Assinatura:

Prof. Dr. Instituição:

Julgamento: Assinatura:

Prof. Dr. Instituição:

Julgamento: Assinatura:

Prof. Dr. Instituição:

Julgamento: Assinatura:

Prof. Dr. Instituição:

Julgamento: Assinatura: 



\section{AGRADECIMENTOS}

Depois de um longo período de pós-graduação - mestrado e doutorado - são muitas as pessoas a agradecer. $\mathrm{Na}$ emergência da escrita, seguramente deixarei algumas pessoas importantes de fora. As que menciono aqui, certamente contribuíram para os acertos e virtudes deste período.

Agradeço ao meu orientador durante o mestrado e doutorado, Professor Fernando Facury Scaff, pelos 6 anos de orientação e pelas incontáveis oportunidades de discussão; por abrir os horizontes e apontar saídas, especialmente naqueles momentos em que os caminhos pareciam confusos.

Aos demais professores do Departamento de Direito Econômico e Financeiro da Faculdade de Direito da Universidade de São Paulo, em especial aos Professores Gilberto Bercovici e Luís Fernando Massonetto, pelas sugestões feitas ao trabalho e pelos debates e lições compartilhadas ao logo do período de doutorado.

À minha coorientadora, Professora Violeta Ruiz Almendral, pela orientação e calorosa recepção em Madrid e pela oportunidade de realizar um período sanduíche na Universidad Carlos III de Madrid. Agradeço aos colegas e professores do Instituto de Derecho Público Comparado "Manuel García Pelayo" de la Universidad Carlos III de Madrid, especialmente a Luis Aguiar de Luque e Gloria Garrido Fernández.

Aos demais professores, professoras e estudantes da Faculdade de Direito da Universidade de São Paulo com quem convivi, especialmente aos amigos da pós-graduação em Direito Financeiro, Isabela Morbach e Alexandre Coutinho da Silveira.

Agradeço à Karem, Rivitti e Murilo (e a todos com quem convivi e convivo no Rivitti e Dias Advogados), pelos 10 anos de ensinamentos, pelas oportunidades que me deram, principalmente a paciência para que eu pudesse concluir o doutorado.

Aos muitos amigos e amigas, que permaneceram ao meu lado e foram companhia nas alegrias e nos momentos de angústia. Raphael, Túlio, Romulo e Gabriel, obrigado pela amizade que segue. Ju, Dante, Ana, Caio, Lu e Javi, pelos momentos marcantes e pela inspiração que cada um de vocês proporciona em mim. Agradecimento especial ao Carlos, pelas divertidas e precisas correções no texto.

Aos amigos de toda uma vida (Falcatrua!) e aos amigos e amigas que recentemente fiz em Madrid - de mais tempo ou menos tempo de convivência, me incentivaram a seguir em frente. Agradeço também à Prainha do Canto Verde, obrigado pelas semanas de acolhimento e também pelo exemplo de luta. 
Agradeço à minha família, especialmente à Tati e ao Brites, pelo amor e pelas lições nos diferentes percursos da vida. À Maria Helena, ao Celso e ao $\mathrm{Gu}$, por sempre me acolherem na família e como família. Dedico aos meus avós, vô Agenor (em memória) e Ba Wanda, que são inspirações desde o passado. Dedico também aos meus afilhados, Benjamim e Enzo, inspirações para o futuro.

Aos meus pais e à minha irmã, Américo, Regina e Marta, pela compreensão na ausência, pela paciência na companhia e pelo amor e dedicação à família seja qual for o momento. Ainda que a retribuição seja sempre insuficiente, dedico o trabalho também a vocês.

Para a Deborah, companheira de vida, amor de mocidade e da eternidade, por todo o carinho e acolhida, na emergência e na normalidade, sem exceção, por estar ao meu lado em todo o meu caminho. Repito que sem você nada disso teria começado, muito menos teria terminado. Agradeço por compartilhar e me acompanhar nos sonhos. A você, dedico todo o trabalho. 


\section{RESUMO}

SILVEIRA, Francisco Secaf Alves Silveira. O estado econômico de emergência e as transformações do Direito Financeiro brasileiro. 2018. 295 f. Tese (Doutorado) - Faculdade de Direito, Universidade de São Paulo, São Paulo, 2018.

O presente trabalho investiga as recentes transformações do Direito Financeiro brasileiro, associadas ao processo de consolidação do estado econômico de emergência. Parte-se da evolução normativa do Direito Financeiro (dever ser) e da transição de um paradigma formal, cuja preocupação central era com os procedimentos de elaboração orçamentária, para um paradigma substantivo, vinculado à constitucionalização das finanças públicas e no qual os objetivos do Direito Financeiro devem se amoldar ao telos constitucional. Na sequência, questiona-se a aderência deste paradigma à realidade (ser), considerando as seguidas crises econômicas e financeiras que bloqueiam a concretização dos objetivos do Direito Constitucional Financeiro. Para analisar os atuais desafios enfrentados pelo Direito Financeiro, utiliza-se a abordagem do estado econômico de emergência, que atualmente se apresenta como uma emergência relacionada ao aspecto econômico, em processo de consolidação e cujas consequências estão relacionadas não apenas à concentração de poderes (como tradicionalmente tratado), mas também à centralização de poder e à flexibilização de procedimentos e direitos individuais e coletivos. Nessa abordagem, as transformações do Direito Financeiro brasileiro são demonstradas por meio de situações concretas de alteração, interpretação e aplicação das normas (práxis constitucional), e são divididas em três âmbitos: separação de poderes, garantia de direitos fundamentais e federalismo fiscal. Por último, ao recuperar o debate entre Kelsen e Schmitt e situações históricas de crise, avaliam-se as reações judiciais ao estado econômico de emergência e às respectivas transformações do Direito Financeiro para, ao final, discutir o risco de mutação do Direito Financeiro contrária ao telos constitucional.

Palavras-chave: Direito Constitucional Financeiro. Estado econômico de emergência. Mutação constitucional. 



\begin{abstract}
SILVEIRA, Francisco Secaf Alves Silveira. The state of economic emergency and the transformations of Brazilian Public Finance Law. 2018. 295 f. Tesis (PhD) - Law School, University of São Paulo, São Paulo, 2018.

The present study investigates the recent transformations of the Brazilian Public Finance Law, associated to the state of economic emergency. First, we explain the normative evolution of the Public Finance Law and the transition from a formal paradigm to a substantive paradigm, which is linked to the constitutionalization of public finance and related to the constitutional objectives. Second, we question how much this substantive paradigm is verified in practice, considering that economic and financial crises have blocked the objectives of the Public Finance Law. In order to investigate the current challenges faced by Public Finance Law, we use the state of economic emergency analysis. Its features are an emergency related to economic issues, in process of consolidation and with consequences related not only to the concentration of powers (as traditionally treated), but also to the centralization of power and to the insufficient rights protection. In this approach, transformations of Brazilian Public Finance Law are demonstrated through concrete situations of changing, interpretation and application of the norms (a constitutional praxis). These transformations are divided into three areas: separation of powers, guarantee of fundamental rights and fiscal federalism. Finally, recovering the debate between Kelsen and Schmitt and also recovering historical situations of crisis, we evaluate the judicial reactions to the state of economic emergency and the transformations of the Law. In the end, we discuss the risk of a Public Finance Law mutation contrary to its constitutional objectives.
\end{abstract}

Keywords: Public Finance Law. State of economic emergency. Constitutional mutation. 



\section{RÉSUMÉ}

SILVEIRA, Francisco Secaf Alves Silveira. L'état d'urgence économique et les transformations du droit budgétaire. 2018. 295 f. Thése (Doctorat) - Faculté de Droit, Université de São Paulo, São Paulo, 2018.

Cette étude vise a examiner les transformations récentes du Droit Budgétaire brésilien, associées à l'état d'urgence économique. Premièrement, nous expliquons l'évolution normative du Droit Budgétaire et la transition d'un paradigme formel, dont la préoccupation centrale était les procédures budgétaires, à un paradigme substantiel, lié à la constitutionnalisation des finances publiques. Deuxièmement, nous nous demandons à quel point ce paradigme substantif est devenu réalité, à cause des crises économiques et financières qui bloquent la réalisation des objectifs de la Constitution. Afin d'étudier les défis actuels rencontrés par le Droit Budgétaire, nous utilisons la théorie de l'état d'urgence économique. Ses caractéristiques sont une urgence liée à des problèmes économiques, en cours de consolidation, et dont les conséquences sont la concentration et la centralisation du pouvoir et à la limitation des droits fondamentaux. Dans cette approche, les transformations du Droit Budgétaire sont démontrées à travers des situations concrètes de changement, d'interprétation et d'application des normes juridiques. Ces transformations sont divisées en trois domaines: la séparation des pouvoirs, la protection des droits fondamentaux et le fédéralisme fiscal. Ensuite, en récupérant le débat entre Kelsen et Schmitt et en récupérant des situations historiques de crise, nous évaluons les réactions judiciaires à l'état d'urgence économique. Finalement, nous discutons le risque d'une mutation du Droit Budgétaire brésilien contraire aux objectifs constitutionnels.

Mots-Clés: Droit Budgétaire. État d'urgence économique. Mutation constitutionnel. 



\section{SUMÁRIO}

INTRODUÇÃO

\section{OS DILEMAS DO DIREITO FINANCEIRO: ENTRE A FORMA E O TELOS CONSTITUCIONAL 23}

1.1. Aspectos históricos do Direito Financeiro

1.2. O primeiro paradigma: o Direito Financeiro como instrumento de controle do monarca pelo Parlamento.

1.3. O segundo paradigma: o Direito Financeiro com conteúdo material a partir da Constituição Social..

1.4. Um terceiro paradigma? Notas sobre o quadro atual do Direito Financeiro.

2. O ESTADO ECONÔMICO DE EMERGÊNCIA COMO NOVO PARADIGMA DO DIREITO FINANCEIRO ........................................ 45

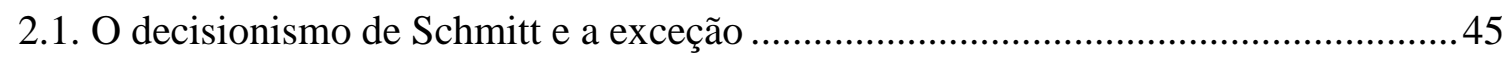

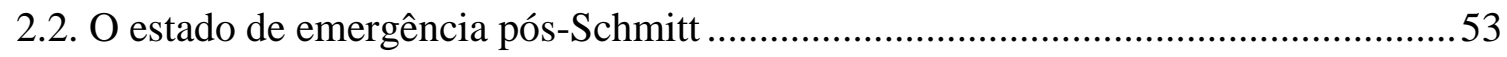

2.3. O processo de consolidação do estado econômico de emergência .

\section{AS TRANSFORMAÇÕES DO DIREITO FINANCEIRO BRASILEIRO DECORRENTES DO ESTADO ECONÔMICO DE

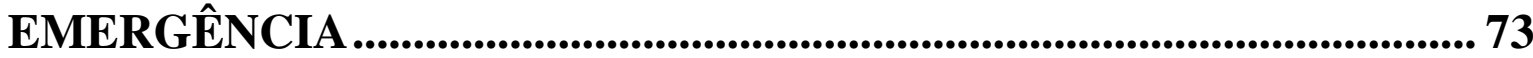

3.1. Delimitação e justificativa acerca do Direito Financeiro e suas transformações .......73

3.2. A concentração da decisão orçamentário-financeira no Executivo e a exclusão do Legislativo .76

3.2.1. A exclusão do Legislativo na elaboração orçamentária: decisão sobre a dívida pública e o resultado primário

3.2.2. O afastamento do Legislativo da execução orçamentária: os decretos de programação financeira e o orçamento de restos a pagar

3.2.3. A abertura de crédito extraordinário e a renovação da emergência 108

3.3. A precária proteção dos direitos fundamentais no âmbito orçamentário-financeiro

3.3.1. Desvinculações de receitas, restrições de direitos e garantia do serviço da dívida

3.3.2. Contingenciamento, resultado primário e a mitigação da execução orçamentária 
3.3.3. A limitação das despesas primárias pelos próximos 20 anos (teto de gastos)..131

3.4. Os desequilíbrios no federalismo fiscal: autonomia conjuntural dos entes subnacionais 144

3.4.1. Financiamento e renegociações de dívida dos entes subnacionais: a recentralização do federalismo fiscal. 154

3.4.2. Os decretos de calamidade financeira dos entes subnacionais 161

3.4.3. Mecanismos alternativos de obtenção de recursos e os riscos ao federalismo: precatórios, depósitos judiciais e securitização da dívida 166

3.5. Síntese sobre as transformações no Direito Financeiro brasileiro .185

4. AS REAÇÕES JUDICIAIS AO ESTADO ECONÔMICO DE EMERGÊNCIA ................................................................................................................ 191

4.1. O debate entre Schmitt e Kelsen sobre o guardião da Constituição........................192

4.2. A dinâmica do Judiciário: reações judiciais ao estado econômico de emergência 199

4.2.1. Alemanha na crise de Weimar ....................................................................220

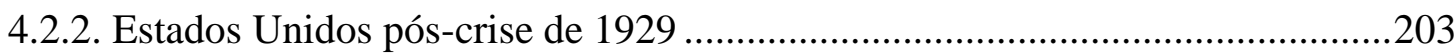

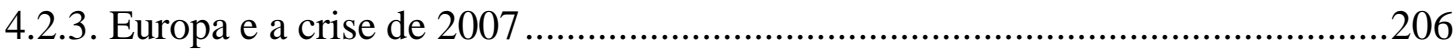

4.2.4. América Latina da década de 90: os casos de Brasil e Argentina ....................217

4.3. Perspectivas do Judiciário brasileiro em face das recentes transformações do Direito

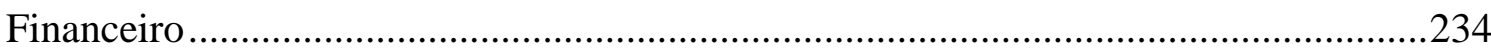

4.4. O risco de mutação da Constituição Financeira contrária a seu telos ......................244

4.5. Para além de Schmitt e Kelsen: a democracia social de Hermann Heller................257

CONCLUSÃ

REFERÊNCIAS BIBLIOGRÁFICAS ....................................................2271 


\section{LISTA DE TABELAS}

Tabela 1. Pacotes de normas europeias de governança macroeconômica e estabilidade orçamentária 92

Tabela 2. Disposições da Lei Orgânica de Estabilidade Orçamentária e Sustentabilidade Financeira da Espanha 97

Tabela 3. Créditos Adicionais - Orçamento Fiscal e Seguridade Social 111

Tabela 4. Categorias de despesas conforme proteção jurídica e obrigatoriedade de execução 126 



\section{INTRODUÇÃO}

A conflitiva relação entre exceção, emergência, Direito e Estado é, há tempos, objeto de controvérsia nas mais diversas ciências. Coloca-se como problema jurídico, político, econômico, social, e atravessa diferentes momentos históricos.

Em Roma, já se decretava o tumultus, "isto é, a situação de emergência (...) provocada por uma guerra externa, uma insurreição ou uma guerra civil”, que autorizava qualquer medida necessária à salvação do Estado e que, por sua vez, dava lugar ao iustitium, ou seja, a interrupção, suspensão do direito ${ }^{1}$. Em Hobbes e com o absolutismo, não haveria espaço para exceção. O soberano é livre para agir e conservar o Estado e não se sujeita às leis civis. A submissão do soberano é, nessa perspectiva, incompatível com a própria natureza do Estado: “o soberano não está sujeito àquelas leis que ele próprio, ou melhor, que o Estado fez. Pois estar sujeito a leis é estar sujeito ao Estado, isto é, ao soberano, ou seja, a si próprio, o que não é sujeição, mas liberdade em relação às leis"2.

Na Revolução Inglesa do século XVII, o "estado de exceção" foi declarado pelo Parlamento para que pudesse agir sem o rei e tomar as medidas necessárias para proteger o povo, independentemente de qualquer direito estabelecido na Constituição ${ }^{3}$. Ao longo do século XIX, inspiradas na lei marcial inglesa (depois adotada na França), as Constituições começam a incluir previsões sobre estado de sítio ou de exceção, como é o caso da Constituição espanhola de Cádiz de 1812, da Constituição Chilena de 1833, da Constituição Francesa de 1848, da Constituição da Argentina de 1853, da Constituição do México de 1857 e da Constituição brasileira de 1891. Com a Primeira Guerra Mundial, o debate sobre a ampliação dos poderes do Executivo (“plenos poderes”) e de novos mecanismos de exceção é levado também para os âmbitos político e econômico, assumindo novos contornos durante o século $\mathrm{XX}^{4}$.

\footnotetext{
${ }^{1}$ AGAMBEN, Giorgio. Estado de Exceção. Trad. Iraci D. Poleti. São Paulo: Boitempo, 2004, p. 67.

${ }^{2}$ HOBBES, Thomas. Leviatã. Coleção Os Pensadores. São Paulo: Editora Nova Cultura, 2010, Segunda Parte, capítulo XXIX. Segundo Gilberto Bercovici, "para Hobbes, não há espaço para a exceção, pois todo o poder é dado ao Estado para se conservar. A teoria hobbesiana da plenitude da soberania torna, portanto, inútil a questão da derrogação do direito comum" (BERCOVICI, Gilberto. Soberania e Constituição: Para Uma Crítica do Constitucionalismo. São Paulo: Quartier Latin, 2008, p. 90).

${ }^{3}$ BERCOVICI, Gilberto. Soberania e Constituição: Para Uma Crítica do Constitucionalismo. São Paulo: Quartier Latin, 2008, p. 96.

${ }^{4}$ Ibidem, pp. 222-285.
} 
Em Carl Schmitt, a própria concepção de Estado e de Direito é construída a partir da exceção ${ }^{5}$. Naquele momento, com a crise da Constituição de Weimar, às vésperas do nazismo e da Segunda Guerra Mundial, revigora-se a discussão sobre a relação entre exceção/emergência e o Direito, a partir de novas perspectivas. Após a teoria de Schmitt se desenvolverá um amplo debate ao longo do século XX sobre a consolidação da emergência e da exceção como paradigma jurídico-político.

Sem pretender uma retomada histórica da exceção e da emergência na teoria do Direito $^{6}$, fato é que tais elementos apresentam desafios à ordem jurídica, ao funcionamento da democracia, à consolidação da Constituição e à construção de um Estado (Social e Democrático) de Direito. Esses desafios se renovam à medida que a sociedade, o Estado e o Direito se transformam ao longo da história. Por essa razão, o tema é há tempos (e ainda) objeto de estudo, sob as mais distintas perspectivas e com reflexos nas mais diversas áreas, embora na área do Direito haja ainda uma "notória resistência no trato da questão"7. Não há uma "teoria do estado de exceção no direito público", já que, em geral, juristas e especialistas em direito público tendem a considerar o problema mais como uma questão de fato, e não como um genuíno problema jurídico ${ }^{8}$. Na presente Tese, tem-se como objeto central o debate sobre a exceção e a emergência no âmbito do Direito e, mais especificamente, no âmbito do Direito Financeiro.

Para compreender essa relação é preciso antes entender as mudanças pelas quais passou a teoria do Direito Financeiro, essencialmente nas três últimas décadas. No Brasil, a Constituição Federal de 1988 estabeleceu uma ampla garantia de direitos civis, políticos e sociais, ampliou a descentralização, a democracia, o dever de transparência e pretendeu colocar o Direito Financeiro dentro de um novo paradigma 9 .

Com a Constituição de 1988, o Direito Financeiro não mais deveria estar relacionado somente a procedimentos de elaboração e aprovação do orçamento, que não mais se

\footnotetext{
${ }^{5}$ Especialmente em SCHMITT, Carl. Teología política. Trad. Francisco Javier Conde; Jorge Navarro Perez. Madrid: Editorial Trotta, 2009.

${ }^{6}$ Para uma análise histórica da exceção como garantia do Estado, da Constituição e do capitalismo, vide BERCOVICI, Gilberto. Soberania e Constituição: Para Uma Crítica do Constitucionalismo. São Paulo: Quartier Latin, 2008.

${ }^{7}$ SERRANO, Pedro Estevam Alves Pinto. Autoritarismo e golpes na América Latina: breve ensaio sobre jurisdição e exceção. São Paulo: Almedina, 2016, p. 16.

${ }^{8}$ AGAMBEN, Giorgio. Estado de Exceção. Trad. Iraci D. Poleti. São Paulo: Boitempo, 2004, p. 11.

9 “A Constituição Federal surgiu como um instrumento de defesa do cidadão contra o poderio do Estado, mas também como um instrumento construtor de uma nova cidadania, implementadora de políticas públicas que permitissem a realização de diversas finalidades estabelecidas na Carta: sociais, educacionais, previdenciárias, ambientais, de proteção às minorias, etc." (SCAFF, Fernando Facury. Constituição Econômica Brasileira em seus 15 anos. Revista de Direito Público da Economia - RDPE, Belo Horizonte, v. 3, jul / set, 2003, p. 62).
} 
caracterizaria como uma mera peça contábil ou um mecanismo de controle do Legislativo sobre o Executivo. $\mathrm{O}$ orçamento e toda a atividade financeira passam a ser submetidos a parâmetros constitucionais não meramente formais e passam a ser regulados por um Direito Financeiro de conteúdo substancial, com aspectos axiológicos, teleológicos, ou seja, valores e finalidades, esses estabelecidos pela Constituição ${ }^{10}$. Daí se falar em um Direito Constitucional Financeiro, em que a obtenção de recursos e a realização de gastos devem visar a efetividade da própria Constituição, de seus direitos, princípios e institutos. Há uma constitucionalização das finanças públicas, em que o propósito da atividade financeira se torna atribuir maior efetividade aos princípios e objetivos constitucionais ${ }^{11}$. Surge um Direito Financeiro relacionado à finalidade, ao telos das normas constitucionais.

Assim, o objetivo do Direito Financeiro, naquele que é seu campo de atuação, passou a se confundir com os próprios objetivos e fundamentos da Constituição: construir uma sociedade livre, justa e solidária; garantir o desenvolvimento nacional; erradicar a pobreza e a marginalização e reduzir as desigualdades sociais e regionais; promover o bem de todos (conforme artigo $3^{\circ}$ ); implementar uma ampla gama de direitos fundamentais, com prevalência de direitos humanos; legitimar e incentivar a participação democrática. Nesse contexto, os direitos fundamentais, como marca da nova ordem constitucional, abrem uma nova função para o Direito Financeiro: “a atividade financeira é por si só um elemento do sistema dos direitos fundamentais e, de outro lado, é também esse sistema que dá sentido à atividade financeira" ${ }^{12}$. Essas, portanto, as finalidades, o telos da Constituição a que se submete o Direito Financeiro.

A mudança de paradigma aqui tratada não é exclusiva do Brasil. Está inserida em um contexto no qual, ao longo do século XX e em diversas partes do Ocidente, houve a adoção de Constituições sociais e, com isso, a tentativa de construir um Estado de Bem-estar Social. Esse movimento certamente influenciou o Direito Financeiro, ainda que em momentos e níveis bastante diferentes, a depender do período e da região.

\footnotetext{
${ }^{10}$ SCAFF, Fernando Facury. Orçamento Republicano e Liberdade Igual: Direito Financeiro, República e Direitos Fundamentais. Tese para o concurso de Professor Titular da Faculdade de Direito Universidade de São Paulo. São Paulo: USP, 2017, p. 96.

${ }^{11}$ Sobre a constitucionalização das finanças públicas e do Direito Financeiro e a mudança de paradigma, vide TORRES, Heleno Taveira. Direito Constitucional Financeiro: Teoria da Constituição Financeira. São Paulo: Editora Revista dos Tribunais, 2014; MENDONÇA, Eduardo Bastos Furtado de. Constitucionalização das Finanças Públicas no Brasil. Rio de Janeiro: Renovar, 2010.

${ }^{12}$ CORTI, Horacio. Derechos fundamentales y presupuesto público. In CONTI, José Maurício; SCAFF, Fernando Facury (coord.). Orçamentos Públicos e Direito Financeiro. São Paulo: Editora Revista dos Tribunais, 2011, pp. 149-150.
} 
Esse novo paradigma normativo ainda buscava bases para se consolidar e, especialmente, em razão das seguidas crises econômicas, encontrou enormes dificuldades em manter aderência à realidade. As condições materiais em se que amparava a construção do Estado de Bem-Estar Social passaram a sofrer cada vez mais pressão diante de seguidas crises, cujas respostas os Estados são cada vez menos capazes de fornecer ${ }^{13}$. A despeito dos avanços normativos, persiste o "mal-estar do mundo jurídico" diante da evolução da sociedade moderna, persiste o "divórcio entre o Direito e a realidade social"14.

Assim, se de um lado a Constituição surgiu como "instrumento construtor de uma nova cidadania, implementadora de políticas públicas" ${ }^{15}$, impondo objetivos ao Direito Financeiro e estabelecendo instrumentos para seu alcance; de outro lado, apresentaram-se severos limites à própria capacidade de intervenção estatal e à consecução desses objetivos.

Nas seguidas crises econômicas, os objetivos constitucionais de consecução de direitos sociais passam a se confrontar com medidas de austeridade, exigência de equilíbrio orçamentário, sustentabilidade da dívida pública e obtenção de credibilidade no mercado internacional. Dentro desse conflito, os pilares em que se fundamentou o novo paradigma do Direito Financeiro passam a ser continuamente questionados: supremacia dos direitos fundamentais, garantia da separação de poderes e equilíbrio no federalismo fiscal, por exemplo $^{16}$. Abre-se espaço para novas transformações do Direito Financeiro, com ameaça aos fundamentos a partir dos quais foi ele normativamente desenhado a partir da Constituição de 1988.

No presente trabalho, as transformações do Direito Financeiro são associadas a um processo de consolidação do estado econômico de emergência, a partir do qual se pretende justificar a flexibilização de garantias e procedimentos, a concentração e a centralização de poderes e a suspensão de direitos. Em nome da emergência econômica, transforma-se o Direito Financeiro, afastando-o de seu telos constitucional. Tem-se aqui a questão central a ser analisada na presente Tese:

\footnotetext{
${ }^{13}$ Conforme STREECK, Wolfgang. As crises do capitalismo democrático. Novos estud. - CEBRAP, São Paulo, n. 92, p. 35-56, Mar. 2012.

${ }^{14}$ COMPARATO, Fabio Konder. O indispensável direito econômico. In COMPARATO, Fabio Konder. Ensaios e Pareceres de Direito Empresarial. Rio de Janeiro: Forense, 1978, p. 453.

${ }^{15}$ SCAFF, Fernando Facury. Constituição Econômica Brasileira em seus 15 anos. Revista de Direito Público da Economia - RDPE, Belo Horizonte, v. 3, jul / set, 2003, p. 62.

${ }^{16}$ Juntamente com os direitos e garantias individuais (aqui limitado aos direitos fundamentais), a forma federativa de Estado e a separação dos Poderes são clausulas pétreas, alcançando, portanto, posição diferenciada na Constituição. Isso ocorre também em outros países, como será apreciado ao longo da presente Tese, com a ressalva de que o federalismo não se verifica em muitos deles.
} 
Como se caracteriza o estado econômico de emergência e quais as consequências sobre o Direito Financeiro brasileiro?

A partir dessa questão e da discussão sobre o estado econômico de emergência, esta Tese tem por objetivo demonstrar a transformação e ressignificação pelas quais tem passado o Direito Financeiro brasileiro delineado desde a Constituição de 1988.

A hipótese adotada é, portanto, a de que o processo de consolidação do estado econômico de emergência tem implicado em uma transformação do Direito Financeiro que substitui o telos constitucional por uma finalidade emergencial e conjuntural. Em outras palavras, a despeito de o Direito Constitucional Financeiro, desde a Constituição de 1988, ser construído teoricamente a partir de sua relação com os objetivos constitucionais, tendo como pilares os direitos fundamentais, a separação de poderes, o federalismo, a transparência e o controle democrático, evidencia-se um processo de consolidação de um estado econômico de emergência, cujo resultado é a ameaça a tais pilares e o esvaziamento do Direito Constitucional Financeiro. Em última instância, sua própria ressignificação.

A hipótese proposta será verificada a partir de três âmbitos de análise, fundamentos/objetivos sobre os quais foi construído o Direito Constitucional Financeiro: (i) a separação de poderes, (ii) a garantia de direitos fundamentais e (iii) o federalismo fiscal. Para cada um desses âmbitos, são apresentadas situações que evidenciam a transformação do Direito Financeiro, relacionadas ao estado econômico de emergência.

Apresentada a questão central e respectiva hipótese, há ainda uma segunda questão a ser enfrentada. Na premissa de um Direito Financeiro em transformação, teria o Poder Judiciário capacidade para controlar tal transformação, exercendo seu papel de "defesa da Constituição"? Em outras palavras, questiona-se:

Qual o papel do Poder Judiciário frente às transformações do Direito Financeiro brasileiro decorrentes do estado econômico de emergência?

Sabe-se que o processo de transformação é conduzido essencialmente pelo Poder Executivo, com a omissão ou anuência do Legislativo. Cabe, entretanto, incluir o Poder Judiciário no debate, a fim de avaliar a relevância de sua participação nesse processo de transformação. A hipótese aqui é a de que o Poder Judiciário também não tem sido capaz, como poder contramajoritário, de refrear a mencionada transformação.

Feitas essas considerações, a presente tese está dividida em quatro capítulos.

No capítulo 1, contextualiza-se a discussão a ser enfrentada, apresentando-se aspectos históricos e as mudanças de paradigma do Direito Financeiro. É o ponto de partida para a análise das transformações do Direito Financeiro. 
No capítulo 2, analisa-se o debate sobre o estado econômico de emergência, começando pelas críticas de Carl Schmitt, abordando as diferentes formas como tal abordagem foi desenvolvida durante a segunda metade do século XX e, ao final, identificando suas características no contexto atual. Trata-se da apresentação do arcabouço teórico a ser utilizado.

No capítulo 3, demonstra-se como o estado econômico de emergência implicou na transformação do Direito Financeiro, mais especificamente, em três âmbitos (parâmetros constitucionais): 1) Separação de poderes; 2) Direitos Fundamentais; e 3) Federalismo. Em cada um desses temas, são identificadas situações que evidenciam mudanças no Direito Financeiro, em sua relação com o estado econômico de emergência. No capítulo 3, respondese a questão central proposta no presente trabalho. Ainda no capítulo 3, dialoga-se com experiências relativas às transformações do Direito Financeiro na Europa, tendo em vista a recente crise pela qual passaram diversos países daquele continente. O paralelo com a Europa revela que a ressignificação de instituições estruturantes de Constituições, que se pretendem sociais e democráticas, não se verifica apenas no Brasil.

No capítulo 4, retomando o debate entre Kelsen e Schmitt sobre o guardião da Constituição, analisa-se o papel do Poder Judiciário e sua capacidade de oferecer respostas às transformações do Direito Financeiro conduzidas em um estado econômico de emergência. $\mathrm{O}$ capítulo 4 tem por objeto justamente enfrentar a segunda questão proposta nesta Tese.

Ao final, a título de conclusão, identifica-se como as transformações debatidas ao longo da Tese, em um contexto de emergência econômica, têm representado um risco de mutação do Direito Constitucional Financeiro contrário a seu telos. 


\section{CONCLUSÃO}

A evolução normativa do Direito Financeiro (dever ser) ao longo dos últimos séculos apontou para uma transição de um paradigma formal, cuja preocupação central eram os procedimentos de elaboração orçamentária, para um paradigma substantivo, vinculado à constitucionalização das finanças públicas, e no qual os objetivos do Direito Financeiro deveriam se amoldar ao telos de uma Constituição social, democrática e com ampla garantia de direitos. Por essa razão, ganha força uma concepção substantivista de Direito Financeiro. Fala-se em Direito Constitucional Financeiro e em efetividade financeira.

As seguidas crises políticas e econômicas e o constante cenário de emergência, entretanto, colocam esse novo paradigma em dificuldades, apontando para a baixa aderência à realidade. O desenho constitucional de 1988, inspirado (ao menos parcialmente) em um modelo de Constituição Social, com ampla garantia de direitos sociais e econômicos, e restabelecendo a democracia no país, enfrentou desde seu início um cenário de emergência econômica que bloqueou constantemente sua concretização. Os grandes desafios da República Federativa do Brasil e de seu Estado Social e Democrático de Direito - construir uma sociedade livre, justa e solidária; garantir o desenvolvimento nacional; erradicar a pobreza e a marginalização e reduzir as desigualdades sociais e regionais; promover o bem de todos (artigo $3^{\circ}, \mathrm{CF}$ ) - parecem distantes, avançam com dificuldades e retrocedem com frequência.

Nesta Tese, a partir do debate sobre o estado econômico de emergência e da análise de situações concretas do Direito Constitucional Financeiro brasileiro no âmbito da separação de poderes, da garantia de direitos fundamentais e do federalismo fiscal, reuniramse elementos voltados a responder à seguinte questão: Como se caracteriza o estado econômico de emergência e quais as consequências sobre o Direito Financeiro brasileiro?

Após revisitar o debate sobre a relação entre Direito e exceção e sobre as atuais concepções do estado econômico de emergência, identificaram-se nele três atributos principais: (i) sua relação cada vez maior com o aspecto econômico; (ii) a existência de um processo de consolidação, ou seja, de perenidade de suas consequências, de "normalização da exceção"; e (iii) suas consequências não apenas relacionadas à concentração de poderes (como mais frequentemente era tratado), mas também com a centralização de poder, com a flexibilização de procedimentos, direitos e garantias individuais e coletivas, com a exclusão 
de outros poderes (e da própria sociedade) no debate político-jurídico, com a fragilização dos pilares jurídico-constitucionais. Assim, na presente Tese, identificou-se um estado econômico de emergência em processo de consolidação, com efeitos sobre a separação de poderes, sobre a divisão interna de poderes/competências (federalismo) e sobre os direitos fundamentais.

O processo de consolidação desse estado econômico de emergência impõe não apenas bloqueio, mas também gradual transformação de três dos pilares fundamentais do Direito Constitucional Financeiro. Mais especificamente, as situações analisadas nesta Tese, com relação (direta ou indireta) com a emergência econômica apontam para (i) Concentração de poderes no Executivo em detrimento do Legislativo, com risco à legitimidade da decisão orçamentária; (ii) Precária proteção dos direitos fundamentais no âmbito orçamentário, com risco de retrocesso e de violação ao núcleo mínimo de tais direitos, especialmente dos direitos sociais; (iii) Autonomia conjuntural dos entes subnacionais, desequilíbrio no federalismo fiscal e recorrente recentralização de poder.

Tais transformações não ocorrem de forma estática e exatamente linear, sendo certo que seus marcos temporais não são exatamente precisos. Na mesma medida em que o capitalismo democrático evolui de forma contraditória, com tensões entre mercado e políticas sociais ${ }^{734}$; da mesma forma que o constitucionalismo (especialmente latinoamericano) evolui com ampliação e restrição de direitos, com redemocratização e concentração de poder; também o Direito Constitucional Financeiro se transforma explicitando suas contradições, evidenciando os conflitos entre o ser e o dever ser, entre a modificação das estruturas e o atendimento da conjuntura.

Ainda, na maior parte dos casos, esse processo de transformação é conduzido pela atuação do Poder Executivo, com ampla utilização de seus instrumentos normativos, usualmente excluindo o Legislativo dos processos decisórios, ou contando com sua omissão ou sua anuência. Essa característica levou à segunda questão proposta, que pretendia incluir o Poder Judiciário no debate, ou seja, discutir qual o papel do Poder Judiciário frente às transformações do Direito Financeiro brasileiro decorrentes do estado econômico de emergência?

A partir da retomada do debate sobre o guardião da Constituição (entre Kelsen e Schmitt), bem como a partir de situações históricas de crise e emergência econômica, o que

\footnotetext{
${ }^{734}$ Conforme STREECK, Wolfgang. Tempo comprado: a crise adiada do capitalismo democrático. Trad. Marian Toldy e Teresa Toldy. Lisboa: Actual editora, 2012; e GRAEBER, David. Dívida: os primeiros 5.000 anos. Trad. Rogério Bettoni. São Paulo: Três Estrelas, 2016.
} 
se verifica é uma fragilidade das reações do Poder Judiciário em face das ações executivas e legislativas em um estado econômico de emergência. Nesse processo de consolidação da emergência, as reações judiciais têm sido insuficientes à conservação e ao aprofundamento do telos constitucional, inclusive quanto às recentes transformações do Direito Financeiro brasileiro. Considerando que muitas das situações (do Direito brasileiro) estudadas na presente Tese ainda se encontram em julgamento, o que impede um diagnóstico preciso acerca do controle judicial, os processos mais recentes indicam sinais contraditórios sobre a proteção dos fundamentos e objetivos constitucionais. Não há indícios suficientes para afastar o risco de consolidação dessas transformações também com a anuência do Poder Judiciário.

Dentro desse contexto, mais grave do que bloqueios momentâneos na concretização do paradigma do Direito Financeiro delineado na Constituição de 1988 é o risco de uma progressiva mutação constitucional contrária ao seu telos. Isto é, o processo de consolidação de um estado econômico de emergência não representa apenas uma frágil concretização dos objetivos do Direito Constitucional Financeiro, mas tal processo evoluiu (ou melhor, regrediu) para uma gradual transformação do Direito Financeiro contrária ao telos constitucional.

Se as inovações colocam em crise instrumentos tradicionais do direito, como afirma Bobbio $^{735}$, as inovações decorrentes da emergência econômica têm colocado em crise a própria Constituição Financeira. Se a ação do Poder Público com vistas à expansão procurava atingir as próprias estruturas do sistema econômico, no sentido de sua transformação, como preconizava Comparato ${ }^{736}$, são as estruturas de uma economia de emergência que agora moldam e restringem a ação do Poder Público, inclusive no âmbito do Direito Financeiro. Tal ação se restringe cada vez mais à conjuntura.

As limitações a que se refere o presente trabalho não são decorrentes apenas da escassez de recursos, especialmente em momentos de crise, mas de imposições políticoeconômicas que propõem um determinado funcionamento às finanças públicas, restrito ao atendimento da emergência econômica. Os fundamentos do Direito Constitucional Financeiro encontram cada vez mais dificuldades de consolidação, abrindo espaços para a aludida transformação: crescente supremacia do serviço da dívida em detrimento dos direitos

\footnotetext{
${ }^{735}$ BOBBIO, Norberto. Da estrutura à função - novos estudos de teoria do direito. Trad. Daniela Versiani. Barueri, SP: Manoli, 2007, p. 02.

${ }^{736}$ COMPARATO, Fabio Konder. O indispensável direito econômico. Ensaios e Pareceres de Direito Empresarial. Rio de Janeiro: Forense, 1978, pp. 464.
} 
fundamentais, opacidade sobrepondo-se à transparência, concentração de poderes no Executivo diante da incapacidade de atuação do Legislativo e do Judiciário, revisão do pacto federativo (com redução da autonomia dos entes subnacionais) - todas esses atributos se tornam dominantes na dinâmica e no modo de operação do Direito Financeiro. A despeito da análise ter sido centrada no Direito Financeiro brasileiro, o fenômeno não é notado apenas aqui, mas teve lugar também na Europa, onde houve profundas transformações no Direito comunitário e nacional - "a crise que se abateu sobre a Europa a partir de 2008 está a transformar-se, perigosamente, numa crise da democracia", afirma Avelãs Nunes ${ }^{737}$.

Assim, o que se vê na dinâmica atual não é mais a de um Direito Financeiro voltado às estruturas das finanças públicas, mas voltado à conjuntura. Luís Fernando Massonetto, a partir de uma perspectiva histórica, já havia identificado um novo padrão normativo do Direito Financeiro, cujos principais atributos são flexibilidade, regulação $a d$ hoc, poderes de emergência, desprestígio da Constituição, aumento progressivo da capacidade normativa do Poder Executivo (em substituição à supremacia do parlamento), execução orçamentária desvinculada das prioridades fixadas no parlamento (e também na Constituição), planejamento restrito a ciclos de curto prazo e o equilíbrio orçamentário como pedra de toque da política fiscal ${ }^{738}$.

Na presente Tese, olhando para a dinâmica normativa, desde as mudanças no texto constitucional até as decisões judiciais, considerando todo o conjunto de atores e instrumentos jurídicos que conformam o Direito Constitucional Financeiro - para sua práxis constitucional - identificou-se o progressivo abandono das estruturas das finanças públicas para o atendimento da emergência e da conjuntura. Eros Grau alertava para um direito que não mais ordenava situações estruturais, mas regulava situações conjunturais, aspecto que impõe que as normas sejam dotadas de flexibilidade, revisibilidade e constante $\operatorname{adaptação~}^{739}$, ou seja, uma legislação de conjuntura, adaptável às mudanças constantes no processo econômico, à instabilidade, a estados econômicos, a permanentes flutuações. Nesse quadro, o Executivo adquire uma capacidade normativa de conjuntura para edição de normas que atendam ao imediatismo, a flutuações, ao dinamismo e à flexibilidade ${ }^{740}$. As dificuldades advindas desse contexto não são exatamente novas, porém, a intensidade com que se

\footnotetext{
${ }^{737}$ NUNES, António José Avelãs. Quo Vadis, Europa? São Paulo: Editora Contracorrete, 2016, p. 145.

${ }^{738}$ MASSONETTO, Luís Fernando. O Direito Financeiro no Capitalismo Contemporâneo: a Emergência de um Novo Padrão Normativo. Tese de Doutorado. Faculdade de Direito da Universidade de São Paulo. São Paulo, 2006, pp. 105-106.

${ }^{739}$ GRAU, Eros. Direito posto e o Direito pressuposto. $7^{\mathrm{a}}$ edição. São Paulo: Malheiros, 2008, p. 27.

${ }^{740}$ GRAU, Eros. Capacidade normativa de conjuntura. Verbete. Enciclopédia Saraiva do Direito. Vol. 14. São Paulo: Saraiva, 1977.
} 
desenvolveu a emergência econômica e, mais preocupante, as consequências da redução do Direito Financeiro ao atendimento da conjuntura é o que renova os desafios que já haviam sido colocados por outros autores (vide seção 1.3).

De outra perspectiva e retomando os debates de Weimar, o que se verifica no atual contexto de consolidação do estado econômico de emergência é o predomínio da saída autoritária de Schmitt (decisionismo de exceção) que, somada à incapacidade do positivismo (judicial) kelseniano, abriu espaço para uma mutação do Direito Constitucional Financeiro, contrária ao telos originalmente delineado em 1988.

Ciente da realidade histórica do momento e ciente da complexidade dos dilemas que se enfrenta, reverter as transformações pelos tradicionais poderes "guardiães da Constituição" se apresenta como uma solução desgastada. O caminho pode estar na vertente que teve menor protagonismo no debate de Weimar, mas cujas ideias se coadunam, em boa parte, com o telos constitucional originalmente traçado pela Constituição de 1988: o aprofundamento da democracia social, voltada ao Estado Social de Direito, capaz de romper o elo entre poder político e econômico ${ }^{741}$. Um caminho entre o "abandono da normatividade em favor do domínio das relações fáticas" e a "normatividade despida de qualquer realidade", que propõe considerar a força normativa da Constituição, de acordo com seu telos original, mas sem ignorar a essencialidade do "substrato espiritual que se consubstancia num determinado povo (suas concepções sociais concretas e o seu baldrame axiológico)". Uma democracia que permita conformar a autoridade das proposições normativas e imprimir ordem e conformação à realidade política e social ${ }^{742}$.

A retomada do telos original do Direito Constitucional Financeiro não pode ser isolada - a Constituição não pode, por si só, realizar nada. Ela impõe tarefas que pretendem concretizar uma determinada ordem, para as quais deve haver um mínimo de vontade, não apenas uma vontade de poder, mas uma vontade de Constituição ${ }^{743}$. A retomada das instituições jurídicas do Direito Financeiro conforme o telos constitucional originalmente delineado pela Constitucional de 1988 exige esforço não apenas dos Poderes constitucionais da República Federativa do Brasil, mas de todos que integram a práxis constitucional “somos todos responsáveis, por ação ou omissão, pela inexistência de uma sociedade mais

\footnotetext{
${ }^{741}$ HELLER, Hermann. Teoria do Estado. Trad. Lycurgo Gomes da Motta. São Paulo: Editora Mestre Jou, 1968, p. 172.

${ }^{742}$ HESSE, Konrad. A Força Normativa da Constituição. Porto Alegre: Sergio Antonio Fabris Editor, 1991, pp. 11-14.

${ }^{743}$ Ibidem.
} 
republicana no Brasil, inclusive e em especial, no âmbito financeiro",744. Daí a relevância de uma democracia que tenha por primeiro objetivo uma igualdade substancial, democracia esta que deve incluir os institutos jusfinanceiros como instrumento voltados ao alcance dessa igualdade. Não há solução milagrosa, nem solução simples. Tampouco a recorrente descrença no Estado de Direito deve prevalecer ${ }^{745}$. Se há um conjunto de atores conformando e contrariando a Constituição, uma solução imediata e centrada num único defensor é regredir aos tempos de Schmitt. Qualquer refundação republicana do constitucionalismo social depende da reinvenção e aprofundamento do princípio democrático, fora da subordinação a uma determinada governabilidade e a uma representação restritiva ${ }^{746}$.

Por essa razão, é fundamental incluir a decisão sobre a dívida pública no debate legislativo e democrático; reforçar o controle sobre a execução orçamentária, reduzindo as distorções causadas pelos decretos de programação financeira e pelos restos a pagar; impedir a utilização abusiva de créditos extraordinários sem os requisitos constitucionais, submetendo-os ao controle; reverter o aumento das desvinculações de receitas, até sua extinção (ainda que de forma gradual); reduzir o protagonismo do contingenciamento, impondo maior transparência na sua utilização, requerendo motivação e maior adequação na execução das políticas públicas; rever a limitação do aumento das despesas primárias pelos próximos 20 anos e, especialmente, a revogação dos orçamentos mínimos da saúde e da educação; retomar o equilíbrio federativo, reduzindo os mecanismos de exceção, seja para escapar às regras de controle, seja para obtenção de recursos de forma pouco transparente. A interpretação das normas de Direito Financeiro e a aplicação de seus institutos devem observar não à emergência imposta pelo Executivo ou pelo Legislativo, mas atender aos preceitos de uma democracia social, voltada à promoção do bem de todos, à redução das desigualdades sociais e regionais.

Remanesce, assim, a pretensão de que o Direito ainda pode servir de parâmetro para a condução da sociedade em tempos de crise, o que depende também do conjunto daqueles que formam a práxis constitucional - "se as pessoas não acreditam no Estado de Direito, o

\footnotetext{
${ }^{744}$ SCAFF, Fernando Facury. Orçamento Republicano e Liberdade Igual: Direito Financeiro, República e Direitos Fundamentais. Tese para o concurso de Professor Titular da Faculdade de Direito Universidade de São Paulo. São Paulo: USP, 2017, p. 764.

${ }^{745}$ Como alerta Hesse, a história constitucional parece ensinar que, tanto na práxis política cotidiana, quanto nas questões fundamentais do Estado, o poder da força afigura-se sempre superior à força das normas jurídicas, a normatividade submete-se à realidade fática. Pode-se recordar, a propósito, tanto o conflito relativo ao orçamento da Prússia, como a mudança do papel político do Parlamento ou, ainda, o exemplo da debacle da Constituição de Weimar (HESSE, Konrad. A Força Normativa da Constituição. Porto Alegre: Sergio Antonio Fabris Editor, 1991, p. 10).

746 PISARELLO, Gerardo. El constitucionalismo social ante la crisis: entre la agonía y la refundación republicano-democrática. Revista Derecho del Estado, nº 28, 2012, p. 60.
} 
Direito não terá força alguma"747. No âmbito do ainda constitucional Direito Financeiro, a refundação de uma práxis constitucional exige aprofundamento da democracia para frear sua transformação num Direito de conjuntura ou num Direito da emergência econômica.

Nesse aspecto, importa menos se esse estado econômico de emergência é realidade incontestável ou mera retórica da crise. Mais ou menos encaixadas, realidade e retórica andam juntas. A realidade jurídica é retórica e a retórica é linguagem, é Direito, como expressão do mais forte ${ }^{748}$. O Direito pode partir da realidade concreta, mas não depende apenas dela para impor sua perspectiva. Isso não significa uma cisão entre norma e realidade (como Schmitt tanto criticou). Ao contrário, representa uma interação entre a norma e a realidade, a partir da qual o Direito se manifesta desde a perspectiva daquele que detém posição política, econômica e social privilegiada.

No processo de consolidação do estado econômico de emergência, importa mais a resposta dada pelo Direito na transformação da realidade do que a veracidade do fundamento. Se reduzido à atual linguagem da emergência econômica, não haverá um Direito Constitucional Financeiro voltado à igualdade, ao federalismo equilibrado, à democracia e à garantia dos direitos fundamentais, ao cumprimento dos objetivos de construção de uma sociedade livre, justa e solidária, de desenvolvimento nacional, de erradicação da pobreza, de redução das desigualdades sociais e promoção do bem de todos. Haverá, de outro lado, um Direito Conjuntural Financeiro, voltado ao atendimento da emergência econômica, normalizando a exceção, instrumentalizando a concentração e a centralização de poderes e também a suspensão permanente dos direitos fundamentais.

\footnotetext{
747 "I just spoke about law's pontential to provide us with moral resources in times of stress. In making that claim, it is important to put emphasis on 'us' and not 'law'. The first president of postwar Germany made the point that the collapse of the Weimar Republic took place not because of flaws in Weimar Constitution, but because in Germany`s first experiment with democracy there were not enough democrats. Similarly, without enough believers in the rule of law, law cannot deliver its resources to us. Moreover, it is not enough that many lawyers and judges are committed to the rule of law. It is important, indeed much more important, that politicians, pubic officials, journalists and plain we the people share this commitment" (grifos nossos) (DYZENHAUS, David. The Constitution of Law: legality in a Time of Emergency. Cambridge: Cambridge University Press, 2006, p. 64).

${ }^{748}$ ADEODATO, João Maurício. Ética e retórica. Para uma teoria da dogmática jurídica. São Paulo: Saraiva, 2002.
} 


\section{REFERÊNCIAS BIBLIOGRÁFICAS}

ABRAHAM, Marcus. Estado de calamidade financeira e a Lei de Responsabilidade Fiscal. In JOTA. Disponível em https://jota.info/colunas/coluna-fiscal/coluna-fiscal-estado-decalamidade-financeira-e-lrf-07072016. Acesso em 25/05/2017.

ABRUCIO, Fernando Luiz. Os Barões da federação: os governadores e a redemocratização brasileira. São Paulo: Hucitec/USP, 1998.

ACKERMAN, Bruce. The emergency constitution. Yale Law Journal, v. 113, n. 5, pp. 10291091, 2004.

ADEODATO, João Maurício. Ética e retórica. Para uma teoria da dogmática jurídica. São Paulo: Saraiva, 2002.

AFONSO, José Roberto; PINTO, Vilma da Conceição. Disponibilidade e Desvinculação financeira. Texto de Discussão n. 39. junho, 2014. FGV - IBRE. Disponível em http://portalibre.fgv.br/main.jsp?lumPageId=402880811D8E34B9011D9CCBFDD1784C \&contentId=8A7C82C546C897580146EF4A8CC77016. Acesso em 31/03/2015.

AGAMBEN, Giorgio. Estado de Exceção. Trad. Iraci D. Poleti. São Paulo: Boitempo, 2004.

ALBORNOZ, Antonio Jiménez-Blanco Carrillo de. La crisis de la deuda pública y la renovación de los conceptos del derecho público: notas para un debate. In: GARCÍA, José Eugenio (dir.); MONTERO, Manuel Estepa. Por el derecho y la libertad: libro homenaje al profesor Juan Alfonso Santamaría Pastor. Madrid: Iustel. 2014.

ALMEIDA, Mansueto; MANOEL, Alexandre; REBOUÇAS, Helder. Os impasses do contingenciamento. Valor Econômico. São Paulo, 02 de março de 2012.

ALMEIDA, Maria Hermínia Tavares de. Recentralizando a federação? Revista de Sociologia e Política, Curitiba: n. 24. 2005.

ALVES, Gustavo Henrique Tardelli. O orçamento federal entre a realidade e a ficção: as armadilhas à transparência da despesa pública no Brasil. Monografia (especialização Curso de Orçamento Público). Instituto Serzedello Corrêa (ISC), 2012.

. A credibilidade do orçamento federal: um desafio à transparência da despesa pública no Brasil. Revista da Controladoria-Geral da União, v. 7, n. 11, 2015.

ARANTES, Rogério Bastos; KERCHE, Fábio. Judiciário e democracia no Brasil. Novos Estudos, 54, pp. 27-41. Cebrap: São Paulo, 1999.

ARMINGEON, Klaus; GUTHMANN, Kai. Democracy in crisis? The declining support for national democracy in European countries, 2007-2011. European Journal of Political Research, v. 53, n. 3, p. 423-442, 2014.

ARRETCHE, Marta. Federalismo e Igualdade Territorial: Uma Contradição em Termos? Revista de Ciências Sociais, Rio de Janeiro, vol. 53, no 3, 2010. 
ARRIGHI, Giovanni. O longo século XX: dinheiro, poder e as origens de nosso tempo. Tradução Vera Ribeiro. Revisão de tradução Cesar Benjamin. Rio de Janeiro: Contraponto; São Paulo: Editora UNESP, 1996.

ASSIS, Luiz Gustavo Bambini. Processo legislativo e orçamento público: a função de controle do parlamento. Tese de Doutorado. Faculdade de Direito da Universidade de São Paulo. São Paulo, 2010.

ASSONI FILHO, Sérgio. Crédito público e responsabilidade fiscal. Porto Alegre: Nuria Fabris Ed. 2007.

ATALIBA, Geraldo. Apontamentos de ciências das finanças, direito financeiro e tributário. São Paulo: RT, 1969.

Empréstimos Públicos e seu Regime Jurídico. São Paulo: Editora Revista dos Tribunais, 1973.

AVALOS, Eduardo. Los decretos de necesidad y urgencia en Argentina: Desde 1853 hasta nuestros días. Revista de la Facultad de Derecho, v. 3, n. 1. Universidad de Córdoba, 2013.

BALERA, Felipe Penteado. Medida Provisória: o controle dos requisitos constitucionais de relevância e urgência pelo Congresso Nacional e pelo STF. Revista brasileira de direito constitucional, v. 14, n. 1, pp. 25-52, 2009.

BANDEIRA, Luiz Alberto Moniz. As políticas neoliberais e a crise na América do Sul. Revista brasileira de política internacional. v. 45, n. 2, pp. 135-146. Brasília, Dezembro, 2002.

BARRETO, Érica de Santana Silva. Os créditos extraordinários e sua excessiva utilização pelo Poder Executivo Federal. Revista Fórum de Direito Financeiro e Econônico - RFDFE, ano 4, n. 6. Belo Horizonte, p. 79-92, 2015.

BARRETO, Paulo Ayres. Contribuições: regime jurídico, destinação e controle. São Paulo: Noeses, 2006.

BARROS, Maurício. Orçamento e Discricionariedade. In CONTI, José Maurício; SCAFF, Fernando Facury (coord.). Orçamentos Públicos e Direito Financeiro. São Paulo: Editora Revista dos Tribunais, 2011.

BATISTA JÚNIOR, Onofre Alves; SALDANHA, Daniel; MAGALHÃES, Tarcísio Diniz. A problemática do uso de depósitos judiciais e extrajudiciais. Revista da Faculdade de Direito da UFMG, nº 69, pp. 501 - 550, Belo Horizonte, n. 69, pp. 501 - 550, jul./dez. 2016.

BELLEGARDE, Marina Tanganelli. Qual a relação entre a Suma Teológica, DRU e retrocesso social?. Revista Fórum de Direito Financeiro e Econônico - RFDFE, ano 5, n. 9. Belo Horizonte, 2016.

BERCOVICI, Gilberto. Constituição e estado de exceção permanente. Atualidade de Weimar. Rio de Janeiro: Azougue editorial, 2004.

O Estado de exceção econômico e a periferia do capitalismo. Pensar - Revista de Ciências Jurídicas, v. 11, 2006. 
; MASSONETTO, Luís Fernando. A Constituição Dirigente Invertida: A Blindagem da Constituição Financeira e a Agonia da Constituição Econômica. Boletim da Faculdade de Direito - Universidade de Coimbra. Suplemento. Coimbra, Portugal, v. XLIX, 2006.

. Soberania e Constituição: Para Uma Crítica do Constitucionalismo. São Paulo: Quartier Latin, 2008.

. O ainda indispensável direito econômico. In BENEVIDES, Maria V. de M.; BERCOVICI, Gilberto; MELO, Claudineu de (Org.). Direitos humanos, democracia e república: homenagem a Fábio Konder Comparato. São Paulo: Quartier Latin, 2009.

BEREIJO, Álvaro Rodriguez. Estudio preliminar. In: LABAND, Paul. Derecho presupuestario. Madrid: Instituto de Estudios Fiscales, 1979.

Disciplina presupuestaria, crisis económica y reforma constitucional. In Crisis y Constitución - XIX Jornadas de la Asociación de Letrados del Tribunal Constitucional. Madrid: Asociación de Letrados del Tribunal Constitucional/ Centro de Estudios Politicos y Constitucionales, pp. 157-218. 2015.

BEUKERS, Thomas. Legal Writings on the Eurozone Crisis. EUI Department of Law Research Paper No. 2015/11. Disponível em http://eurocrisislaw.eui.eu/wpcontent/uploads/2015/04/LAW_2015_11-Beukers.pdf. Acesso em 05/04/2016.

BEZERRA, Marcos O. Em nome das “bases”. Política, favor e dependência pessoal. Rio de Janeiro: Relume-Dumará, 1999.

BICALHO, Lucídio. Jogos orçamentários. Nota Técnica n. 176. Brasília: INESC, dezembro de 2011.

BLUSTEIN, Paul. Vexame: bastidores do FMI na crise que abalou o sistema financeiro mundial. Rio de Janeiro: Record, 2002.

BOBBIO, Norberto. Da estrutura à função - novos estudos de teoria do direito. Trad. Daniela Versiani. Barueri, SP: Manoli, 2007.

BOLONHA, Carlos; RANGEL, Henrique; CORRÊA, Flávio. Hiperpresidencialismo na América Latina. Revista da Faculdade de Direito UFPR, v. 60, n. 2, p. 115-140, 2015.

BONAVIDES, Paulo. Curso de Direito Constitucional. 28a Ed. São Paulo: Editora Malheiros, 2013.

BOUVIER, Michel. La soutenabilité des finances publiques en déficit de projet politique. Revue Française de Finances Publiques nº 118. França: Fondafip, 2012.

BRITO, Miguel Nogueira de. Putting Social Rights in Brackets? The Portuguese Experience with Welfare Challenges in Times of Crisis. In KILPATRICK, Claire; DE WITTE, Bruno (eds.). Social rights in times of crisis in the Eurozone: The role of fundamental rights' challenges. EUI Working Papers LAW 2014/05. Fiesole: European University Institute, 2014. 
BUDINA, Nina; Schaechter, Andrea; Weber, Anke; Kinda, Tidiane. Fiscal Rules in Response to the Crisis: Toward the" Next-Generation" Rules: A New Dataset. IMF Working Paper/12/187. International Monetary Fund. julho. 2012.

CABRAL, Nazaré da Costa. Programa e decisão orçamental: da racionalidade das decisões orçamentais à racionalidade econômica. Coimbra: Almedina, 2008.

CALLEJÓN, Francisco Balaguer. Crisis económica y crisis constitucional en Europa. Revista Española de Derecho Constitucional, pp. 91-107, 2013.

CAMPOS, Carlos Alexandre de Azevedo. Da Inconstitucionalidade por Omissão ao "Estado de Coisas Inconstitucional". Tese de Doutorado em Direito Público. Faculdade de Direito Universidade do Estado do Rio de Janeiro. 2015.

CAMPOS, Francisco. Orçamento - natureza jurídica - lei material e lei formal - exposição e crítica da doutrina de Leband - direito comparado - elevação do imposto de vendas e consignações em São Paulo. Revista de Direito Administrativo, v. 14, p. 447-467. Rio de Janeiro, out. 1948. 1963.

Orçamento - Natureza jurídica. Revista de Direito Administrativo 71/324. jan./mar.

CANOTILHO, J. J. Gomes. Constituição Dirigente e vinculação do legislador. Coimbra: Coimbra ed., 1994.

Gomes. Direito Constitucional e Teoria da Constituição. $7^{\mathrm{a}}$ ed. Coimbra: Almedina, pp. 1.200-1.201. 2003.

CARVALHO, André Castro. Vinculação de Receitas Públicas. São Paulo: Quartier Latin, 2010.

Direito Constitucional Financeiro e Direito Orçamentário Substantivo. In CONTI, José Maurício; SCAFF, Fernando Facury (coord.). Orçamentos Públicos e Direito Financeiro. São Paulo: Editora Revista dos Tribunais, 2011.

CASTILLO ORTIZ, Pablo José. La crisis y las transformaciones del derecho público estatal y europeo vistas por la academia española. Revista de Estudios Políticos, v. 165, p. 281-304, 2014.

CASTRO, Marcus Faro de. O Supremo Tribunal Federal e a Judicialização da Política. Revista Brasileira de Ciências Sociais, vol. 12, nº 34, pp. 147-156, 1997.

CAYUSO, Susana. La emergencia económica y la Constitución. Crónica de un pasado y presente contradictorios y de un futuro incierto. En busca de los controles perdidos. Revista Jurídica Argentina La Ley, p. 1319-1343, 2005.

CHRISTOPOULOS, Basile. Orçamento público e controle de constitucionalidade. Rio de Janeiro: Lumen Juris, 2016.

CISOTTA, Roberto; GALLO, Daniele. The Portuguese Constitutional Court case law on austerity measures: a reappraisal. In KILPATRICK, Claire; DE WITTE, Bruno (eds.). Social 
rights in times of crisis in the Eurozone: The role of fundamental rights' challenges. EUI Working Papers LAW 2014/05. Fiesole: European University Institute, 2014.

CLOSA, Carlos. Los cambios institucionales en la gobernanza macroeconómica y fiscal de la UE: hacia una mutación constitucional europea. Revista de Estudios Políticos, n. 165, p. 5786, 2014.

COLE, David. Judging the next emergency: judicial review and individual rights in times of crisis. Michigan Law Review, v. 101, n. 8, p. 2565-2595, 2003.

COMISKEY, Michael. Can a President Pack or Draft the Supreme Court-FDR and the Court in the Great Depression and World War II. Albany Law Review, v. 57, 1993.

COMPARATO, Fabio Konder. O indispensável direito econômico. Ensaios e Pareceres de Direito Empresarial. Rio de Janeiro: Forense, 1978.

CONTI, José Maurício. A autonomia Financeira do Poder Judiciário. São Paulo: MP Editora, 2006.

Emendas ao Orçamento e o Desequilíbrio de poderes. Disponível em http://www.conjur.com.br/2012-jul-03/contas-vista-emendas-orcamento-desequilibriopoderes. Acesso em 07/05/2015.

O final de anos, as dívidas e os restos a pagar. Conjur - Contas à vista. Disponível em http://www.conjur.com.br/2013-dez-17/contas-vista-final-ano-dividas-restos-pagar. Acesso em 24/05/2017.

O final de anos, as dívidas e os restos a pagar. Conjur - Contas à vista. Disponível em http://www.conjur.com.br/2013-dez-17/contas-vista-final-ano-dividas-restos-pagar. Acesso em 24/05/2017.

CORREIA NETO, Celso de Bastos. O STF, o orçamento e os créditos extraordinários. In Conjur-Observatório Constitucional. Disponível em https://www.conjur.com.br/2013-fev23/observatorio-constitucional-stf-orcamento-creditos-extraordinarios\#_ftn3. Acesso em 01/11/2017.

CORTI, Horacio. Derecho Financiero. Buenos Aires: Alberto Perrot, 1997.

Derechos fundamentales y presupuesto público. In CONTI, José Maurício; SCAFF, Fernando Facury (coord.). Orçamentos Públicos e Direito Financeiro. São Paulo: Editora Revista dos Tribunais, 2011.

Las restricciones presupuestarias en la jurisprudencia de la Corte Suprema de Justicia argentina. Lex Social: Revista de Derechos Sociales, v. 7, n. 1, p. 144-173, 2017.

Ley de presupuesto y derechos fundamentales: los fundamentos de un nuevo paradigma jurídico-financiero. Revista Jurídica de Buenos Aires, v. 1, 2010.

COUTTS, Stephen; DÍEZ SÁNCHEZ, Leticia; MARKETOU, Afroditi-Ioanna; PIERDOMINICI, Leonardo. Legal Manifestations of the Emergency in National Euro Crisis Law. EUI Department of Law Research Paper No. 2015/14. Disponível em 
http://eurocrisislaw.eui.eu/wp-content/uploads/2015/05/LAW_2015_14.pdf. Acesso em 04/04/2016.

DA ROCHA, Diones Gomes; MARCELINO, Gileno Fernandes; SANTANA, Cláudio Moreira. Orçamento público no Brasil: a utilização do crédito extraordinário como mecanismo de adequação da execução orçamentária brasileira. Revista de Administração, v. 48, n. 4, p. 813-827, 2013.

DE OLIVEIRA, Leandro Saraiva Dantas; LIMA, Roberto José Vieira de Sousa, PAULO, Edilson, LUCENA, Wenner Glaucio Lopes Lucena. Dívida Ativa: Evidenciação e Fatores de Influência em sua Recuperabilidade. In: $1^{\circ}$ Congresso da UnB de Contabilidade $e$ Governança. 2016.

DE OLIVEIRA, Vanessa Elias. Judiciário e privatizações no Brasil: existe uma judicialização da política? Revista de Ciências Sociais, vol. 48, n. 3. Rio de Janeiro, pp. 559 a 587. 2005.

DE WITTE, Bruno. Euro Crisis Responses and the EU Legal Order: Increased Institutional Variation or Constitutional Mutation? European Constitutional Law Review, v. 11, n. 03, p. 434-457, 2015.

DIAS, Fernando Álvares Correia. O que é e para que serve a DRU? (2011). Disponível em https://goo.gl/BGLrta. Acesso em 22/06/2016.

DÍEZ SÁNCHEZ, Leticia. Desconstitutionalisation of social rights and the quest for efficiency. In KILPATRICK, Claire; DE WITTE, Bruno (eds.). Social rights in times of crisis in the Eurozone: The role of fundamental rights' challenges. EUI Working Papers LAW 2014/05. Fiesole: European University Institute, 2014.

DUBBER, Markus Dirk. Judicial Positivism and Hitler's Injustice. Columbia Law Review, 1993.

DUGARD, John. The Judiciary in a State of National Crisis - With Special Reference to the South African Experience. Wash. \& Lee L. Rev., v. 44, pp. 483-484. 1987.

DURAN, Camila Villard. O Supremo Tribunal Federal e a construção jurisprudencial da moldura jurídica do poder monetário. Direito, Gestão e Democracia. Brasília: EAGU, 2011, p. 77.

DYZENHAUS, David. Hermann Heller. An Introduction. Cardozo Law Review. v. 18, p. 1129, 1996.

Legal Theory in the Collapse of Weimar: Contemporary Lessons? The American Political Science Review, vol. 91, n. 1, pp. 121-134. 1997.

. Legality and Legitmacy. Carl Schmitt, Hans Kelsen and Hermann Heller in Weimar. Oxford: Oxford University Press, 1997.

Schmitt v. Dicey: Are States of Emergency Inside or Outside the Legal Order?”. Cardozo Law Review. vol. 27, 2005.

. The Constitution of Law: legality in a Time of Emergency. Cambridge: Cambridge University Press, 2006. 
. Kelsen, Heller and Schmitt: Paradigms of Sovereignty Thought. Theoretical Inquiries in Law, v. 16, n. 2, p. 337-366, 2015.

ECHEVESTE, José Luis Burlada. Límites y garantías constitucionales de la Deuda pública. In LEÓN, José Maria Baño (coord.). Memorial para la reforma del Estado: Estudios en homenaje al Profesor Santiago Muñoz Machado. Madrid: Centro de Estudios Politicos Constitucionales, p. 2883-2909. 2016.

ELIAS, Norbert. O processo civilizador. Trad. Ruy Jungmann; revisão de Renato Janine Ribeiro. Rio de Janeiro: Jorge Zahar, 1994.

FABBRINI, Frederico. The fiscal compact, the 'golden rule' and the paradox of European federalism. Boston College International \& Comparative Law Review, v. 36, n. 1, 2013.

. The Euro-Crisis and the Courts: Judicial Review and the Political Process in Comparative Perspective. Berkeley Journal of International Law, v. 32, 2014.

FAGUNDES, M. Seabra. Novas perspectivas do federalismo brasileiro. Revista de Direito Administrativo. Rio de Janeiro: Revista dos Tribunais, 99:01-11, 1970.

FAHEY, Elaine; BARDUTZKY, Samo. Judicial Review of Eurozone Law: The Adjudication of Postnational Norms in Eu Courts, Plural-A Casestudy of The European Stability Mechanism. Amsterdam Centre for European Law and Governance - Working Paper Series 2013. Disponível em http://ssrn.com/abstract=2287917. Acesso em 15/06/2017.

FARIA, José Eduardo. Antinomias jurídicas e gestão econômica. Lua Nova, São Paulo, n. 25, p. 141-166. Abril, 1992.

A crise do Judiciário no Brasil. In LIMA JR., Jayme Benvenuto (org.). Independência dos juízes: aspectos relevantes, casos e recomendações. Recife: Gajop; Bagaço, 2005.

FASONE, Cristina. Constitutional courts facing the Euro crisis: Italy, Portugal and Spain in a comparative perspective. EUI working papers 2014/15. European University Institute, 2014.

Taking budgetary powers away from national parliaments? On parliamentary prerogatives in the Eurozone crisis. EUI Department of Law Research Paper No. 2015/37. Disponível em http://eurocrisislaw.eui.eu/wp-content/uploads/2015/08/LAW_2015_37.pdf. Acesso em 04/04/2016).

FEREJOHN, John; PASQUINO, Pasquale. The law of exception: a typology of emergency powers. International Journal of Constitutional Law 2.2, Oxford University Press and New York University School of Law, 2004.

FERRAZ, Anna Cândida da Cunha. Processos informais de mudança da Constituição: mutações constitucionais e mutações inconstitucionais. Osasco: EdiFIEO, 2015.

FGV. CPDOC. Dicionário. Verbete Estado de sítio. Disponível em http://www.fgv.br/cpdoc/acervo/dicionarios/verbete-tematico/estado-de-sitio. Acesso em $12 / 10 / 2017$. 
FGV. DAPP. A evolução dos restos a pagar nas leis orçamentárias de 2001 a 2014 Estudos estratégicos - vol. 04 . Disponível em <http://dapp.fgv.br/wpcontent/uploads/2016/02/DAPPestudos_vol4_final_com_capa.pdf $>$. Acesso em 24/05/2017.

FIORI, José Luís. Estado de bem-estar social: padrões e crises. Physis: Revista de Saúde Coletiva, v. 7, n. 2, p. 129-147, 1997.

FONSECA, Rafael Campos Soares da. O orçamento público e suas emergências programadas: um estudo sobre a abertura de créditos extraordinários por medida provisória (2008-2015). Dissertação de Mestrado. Universidade de Brasília, 2016.

FRANCO NETO, Georgenor de Sousa. O uso dos depósitos judiciais e administrativos como fonte de receita: uma análise acerca da constitucionalidade da Lei Complementar $\mathrm{n}$. 151/2015. Revista Fórum de Direito Financeiro e Econônico - RFDFE, ano 5, n. 9. Belo Horizonte, 2016.

FREITAS, Leonardo Buissa; BEVILACQUA, Lucas. Atividade financeira do Estado, transferências intergovernamentais e políticas públicas no federalismo físcal brasileiro. Revista Fórum de Direito Financeiro e Econônico - RFDFE, ano 5, n. 9. Belo Horizonte, 2016.

FREITAS, Paulo Springer de; MENDES, Francisco Schertel. Comentários sobre a PEC do teto dos gastos públicos aprovada na Câmara dos Deputados: necessidade e constitucionalidade da medida. Boletim Legislativo $n^{o}$ 55. Núcleo de Estudos e Pesquisas da Consultoria Legislativa do Senado Federal. Novembro de 2016.

FUSO, Rafael Correia. Regimes tributário na securitização de títulos e valores mobiliários: lucro real e lucro presumido. Tese de Doutorado. Pontifícia Universidade Católica. PUCSP. São Paulo. 2016.

GARGARELLA, Roberto. What Courts should not do: Argentina. In GLOPPEN, Siri et al. (edtors). Democratization and the Judiciary. London: Frank Cass, 2004.

. Latin America Constitucionalism, 1810-2010. The Engine Room of the Constitution. Oxford: Oxford University Press, 2013.

. Constitucionalismo latino-americano: a necessidade prioritária de uma reforma política. In RIBAS, Luiz Otávio (Organizador). Constituinte exclusivo: um outro sistema político é possível. São Paulo: Expressão Popular, 2014.

GARZÓN VALDÉS, Ernesto. Derecho y democracia en América Latina. Revista Isonomia $n^{o}$ 14. México: Instituto Tecnológico Autónomo, abril de 2001.

GINSBORG, Lisa. The impact of the economic crisis on human rights in Europe and the accountability of international institutions Global Campus Human Rights Journal, pp. 97$117,2017$.

GONTIJO, Vander. Orçamento impositivo, contingenciamento e transparência. Cadernos Aslegis, n. 39, p. 61-72, jan/abr 2010. 
GONZÁLEZ, Eva María Cordero. La reforma de la constitución financiera alemana. En particular, el nuevo límite al endeudamiento de la federación y los länder. Teoría y realidad constitucional $\mathrm{n}^{\circ} 29.2012$.

GONZALEZ, Horacio Ricardo. Estado de no derecho: emergência y derechos constitucionales. Colección Tesis Doctoral. Buenos Aires: Del Puerto, 2007.

GRAEBER, David. Dívida: os primeiros 5.000 anos. Trad. Rogério Bettoni. São Paulo: Três Estrelas, 2016.

GRAU, Eros. Capacidade normativa de conjuntura. Verbete. Enciclopédia Saraiva do Direito. Vol. 14. São Paulo: Saraiva, 1977.

Direito posto e o Direito pressuposto. $7^{\text {a }}$ edição. São Paulo: Malheiros, 2008.

GROSS, Oren; AOLÁIN, Fionnuala Ní. Law in times of crisis: emergency powers in theory and practice. Cambridge: Cambridge University Press, 2006.

GUERRERO, Manuel Medina. El Estado autonómico en tiempos de disciplina fiscal. Revista española de derecho constitucional, v. 33, n. 98, 2013.

GUILLÉN, Ana M.; GONZÁLEZ-BEGEGA, Sergio; BALBONA, David Luque. Austeridad y ajustes sociales en el Sur de Europa. La fragmentación del modelo de bienestar Mediterráneo. Revista Española de Sociología (RES), v. 25, n. 2, p. 261-272, 2016.

HABER NETO, Michel. A tributação e o financiamento do direito à saúde no Brasil. Dissertação de Mestrado em Direito. Faculdade de Direito da Universidade de São Paulo. São Paulo, 2012.

HABERMAS, Jürgen. Democracy, solidarity and the European crisis. In GROZELIER, AnneMarie et al. Roadmap to a Social Europe. Social Europe. Brussels: Hans Böckler Stiftung, 2013.

HARVEY, David. O novo imperialismo. Trad. Adail Sobral e Maria Stela Gonçalves. $6^{\text {a }}$ edição. São Paulo: Edições Loyola, 2012.

HELLER, Hermann. Teoria do Estado. Trad. Lycurgo Gomes da Motta. São Paulo: Editora Mestre Jou, 1968. 2004.

. Las ideas políticas contemporâneas. Trad. Manuel Pedroso. Granada: Ed. Comares,

HERNÁNDEZ, Antonio María. Las emergencias y el orden constitucional. Cordoba: Universidad Nacional Autónoma de México, 2003.

A Tres Lustros de la Reforma Constitucional de 1994. Revista de la Faculdad de Derecho de México, Vol. 60, 254, 2010.

HESSE, Konrad. A Força Normativa da Constituição. Porto Alegre: Sergio Antonio Fabris Editor, 1991. 
HIRST, Paul. Carl Schmitt's Decisionism. Telos $n^{\circ} 72$ (A Quarterly of critical thought). New York: Telos Press, Summer 1987.

HOBBES, Thomas. Leviatã. Coleção Os Pensadores. São Paulo: Editora Nova Cultura, 2010.

HOLMES, Stephen; SUNSTEIN, Cass R. The Cost of Rights - why liberty depend on taxes. New York: W.W.Norton \& Company, 1999.

JELLINEK, Georg. Reforma y mutación de la Constitución. Madrid: Centro de Estudios Constitucionales, 1991.

JUNIOR, Ronaldo Jorge Araujo Vieira. As inconstitucionalidades do "Novo Regime Fiscal" instituído pela PEC $\mathrm{n}^{\circ}$ 55, de 2016 (PEC n 241, de 2016, na Câmara dos Deputados). Boletim Legislativo $n^{o}$ 53. Núcleo de Estudos e Pesquisas Legislativas da Consulltoria Legislativo do Senado Federal. Novembro, 2016.

KAUFMANN, Arthur. National Socialism and German Jurisprudence From 19331945. Cardozo Law Review, v. 9, 1987.

KELSEN, Hans. Teoria Pura do Direito. Trad. João Baptista Machado. $6^{a}$ edição. São Paulo: Martins Fontes, 1999

. Quem deve ser o guardião da Constituição? In KELSEN, Hans. Jurisdição Constitucional. São Paulo: Martins Fontes, 2003.

KENNEDY, Ellen. Introduction to Hermann Heller. Economy and Society, v. 16, n. 1, pp. 120126, 1987.

. Emergency Government Within the Bounds of the Constitution: An Introduction to Carl Schmitt, "The Dictatorship of the Reich president according to Article 48 RV”. Constellations, v. 18, n. 3, pp. 284-297, 2011.

. Carl Schmitt em la República de Weimar. trad. de Pedro Lomba Falcón. Madrid: Tecnos, 2012.

KILPATRICK, Claire. Constitutions, social rights and sovereign debt states in Europe: a challenging new area of constitutional inquiry. EUI Department of Law Research Paper No. 2015/34. Disponível em http://eurocrisislaw.eui.eu/wpcontent/uploads/2015/06/LAW_2015_34.pdf. Acesso em 04/04/2016).

On the Rule of Law and Economic Emergency: The Degradation of Basic Legal Values in Europe's Bailouts. Oxford Journal of Legal Studies, v. 35, n. 2, pp. 325-353, 2015.

KÖLLING, Mario. Los límites de la deuda pública según la reforma de la Ley Fundamental alemana de 2009. Revista d'estudis autonòmics i federals, n. 16, 2012.

LABAND, Paul. Derecho presupuestario. Madrid: Instituto de Estudios Fiscales, 1979.

LEGRAIN, Milli. La crisis argentina de diciembre de 2001. Debilidad institucional y falta de legitimidad del Estado. Universidad Complutense de Madrid, Instituto Complutense de Estudios Internacionales, 2004. 
LIMA, Martônio Mont'alverne Barreto; LEITÃO, Rômulo Guilherme; CHAVES, Daniel, Rocha. Risco de Sempre: Poder Judiciário na Democracia. In: Lima, Martonio Mont'Alverne Barreto; Carmo, Valter Moura do; Coutinho, Júlia Maia de Meneses. (Orgs.). Progresso e Regresso político. $1^{\mathrm{a}}$ ed. Rio de Janeiro: A Livraria e Editora Lumen Juris Ltda, v. 01, p. 327-338. 2017.

LLEDÓ, Victor; YOON, Sungwook; FANG, Xiangming; MBAYE, Samba; KIM, Young. Fiscal Rules at a Glance. International Monetary Fund. Março, 2017.

LOCHAGIN, Gabriel Loretto. A execução do orçamento público: flexibilidade e orçamento impositivo. São Paulo: Blucher, 2016.

LOSADA, Fernando. Exacerbated Economic Governance in the European Union-Or When Did We Forget About Democratic Legitimacy? Legal Studies Research Paper Series, no 24. University of Helsinki, 2013. Disponível em http://ssrn.com/abstract=2261123. Acesso em $14 / 06 / 2017$.

MACEDO JR., Ronaldo Porto. Carl Schmitt e a fundamentação do direito. São Paulo: Max Limonad, 2001.

MACHADO E SILVA, Isabela Morbach. O sistema orçamentário brasileiro, planejamento e políticas públicas. Revista Fórum de Direito Financeiro e Econônico - RFDFE, ano 4, n. 6. Belo Horizonte, p. 109-122, 2015.

MARTINICO, Giuseppe. The Impact of the Treaty on Stability, Coordination, and Governance on the National Constitutional Structure: A Regional Example. Michigan Journal of International Law. Emerging Scholarship Projecto. Julho, 2013.

MARTINS, Ana Maria Guerra. Constitutional Judge, Social Rights and Public Debt Crisis: The Portuguese Constitutional Case Law. Maastricht Journal of European and Comparative Law, v. 22, n. 5, 2015.

MARTINS, Marcelo Guerra. As vinculações das receitas públicas no orçamento. A Desvinculação das Receitas da União (DRU). As contribuições e a referibilidade. In CONTI, J. Maurício; SCAFF, Fernando F. (coords.). Orçamentos públicos e direito financeiro. São Paulo: Revista dos Tribunais, 2011.

MARX, Karl. O capital. Livro 01: O processo de produção do capital. Vol. 02. $3^{\text {a }}$ ed. Rio de Janeiro: Editora Civilização Brasileira, 1975.

MÀS, Joaquín Tornos. Derechos sociales, comunidades autónomas y crisis económica. Instituto de Derecho Publico de Barcelona. Informe Comunidades Autónomas 2016. Disponível em https://www.foroautonomias.es/. Acesso em 10/12/2017.

MASALA, Pietro. El impacto de la crisis económica y de la reforma constitucional de 2012 en la jurisprudencia de la Corte Constitucional italiana en materia de ponderación entre los derechos sociales prestacionales y la estabilidad presupuestaria. In Anuario Iberoamericano de Justicia Constitucional, n. 20, p. 223-255, 2016.

MASSONETTO, Luís Fernando. O Direito Financeiro no Capitalismo Contemporâneo: a Emergência de um Novo Padrão Normativo. Tese de Doutorado. Faculdade de Direito da Universidade de São Paulo. São Paulo, 2006. 
Os impactos da expansão financeira do capitalismo mundial - a constituição de um novo paradigma. In HORVATH, Estevão; CONTI, José Mauricio; SCAFF, Fernando Facury (orgs.). Direito Financeiro Econômico e Tibutário. Estudos em homenagem a Regis Fernandes de Oliveira. São Paulo: Quartier Latin, 2014.

MAUS, Ingeborg. Judiciário como superego da sociedade: o papel da atividade jurisprudencial na "sociedade órfã”. Novos estudos CEBRAP, v. 58, pp. 183-202, 2000.

MELO DELGADO, Rosa Herlinda. El estado de excepción en el actual constitucionalismo andino. Quito: Universidad Andina Simón Bolívar, Corporación Editora Nacional, 2015.

MELO, Carlos Antonio de Almeida. Mecanismos de proteção e concretização constitucional: proposta de uma ação de concretização da Constituição. In SCAFF, Fernando Facury (org.). Constitucionalizando Direitos: 15 anos da Constituição Brasileira de 1988. Rio de Janeiro: Renovar, 2003.

MENDES, Marcos J. Sistema orçamentário brasileiro: planejamento, equilíbrio fiscal e qualidade do gasto público. Texto para discussão 39. Brasília: Consultoria Legislativa do Senado Federal, 2008.

MENDONÇA, Eduardo Bastos Furtado de. Constitucionalização das Finanças Públicas no Brasil. Rio de Janeiro: Renovar, 2010.

MENÉNDEZ, Agustín José. La mutación constitucional de la Unión Europea. Revista española de derecho constitucional, v. 32, n. 96, p. 41-98, 2012.

MENEZES, Dyelle. Recorde: “Orçamento Paralelo" deve somar R\$ 240,1 bilhões em 2014. Contas Abertas. Disponível em: http://www.contasabertas.com.br/website/arquivos/7413. Acesso em 24/05/2017.

MORA, Mônica; GIAMBIAGI, Fabio. Federalismo e endividamento subnacional: uma discussão sobre a sustentabilidade da dívida estadual e municipal. Texto pra Discussão $n^{o}$ 1142. IPEA, 2005.

NAGEL, Stuart S. Court-curbing periods in American history. Vanderbilt Law Review, v. 18, p. 925, 1964.

NAGLE, Luz Estella. La cenicienta del gobierno: reforma a la justicia en América Latina. In SILVA, German Burgos (Eds.) Independencia Judicial en America Latina. ¿De quién? ¿Para qué? ¿Cómo? Bogotá: Instituto Latinoamericano de Servicios Legales Alternativos, 2003.

NEGRETTO, Gabriel. Paradojas de la reforma constitucional en América Latina. Journal of Democracy en español, v. 1, n. 1, pp. 38-54, 2009.

. Shifting Constitutional Designs in Latin America: A Two-Level Explanation. 2011.

NELSON, Michael. The President and the court: Reinterpreting the court-packing episode of 1937. Political Science Quarterly, v. 103, n. 2, pp. 267-293, 1988. 
NEVES, Marcelo. Constitucionalização simbólica e desconstitucionalização fática: mudança simbólica da Constituição e permanência das estruturas reais de poder. Revista de Informação Legislativa, nº 132. Brasília: Senado Federal, out/dez, 1996.

NUNES, António José Avelãs. Quo Vadis, Europa? São Paulo: Editora Contracorrente, 2016.

Setenta anos depois da derrota do nazi-fascimo, 'na Europa fala-se alemã'. In: Lima, Martonio Mont'Alverne Barreto; Carmo, Valter Moura do; Coutinho, Júlia Maia de Meneses. (Orgs.). Progresso e regresso político: a democracia em risco. Rio de Janeiro: Editora Lumen Juris, 2017.

O’DONNELL, Guillermo. Democracia Delegativa. Journal of Democracy (en español). Vol. 5, n. 1, pp. 55-69. Janeiro, 1994.

OLIVEIRA, Júlio Marcelo de. Securitização da dívida ativa enfraquece a responsabilidade fiscal. In Conjur - Contas à vista. Disponível em https://goo.gl/dou4Ng. Acesso em 05/11/2017.

OLIVEIRA, Rafael Tomaz; SCARPINO JÚNIOR, Luiz Eugênio. Securitização da dívida não pode ser simples política de governo. Conjur. Disponível em https://www.conjur.com.br/2015-jul-11/diario-classe-securitizacao-divida-ativa-naopolitica-governo. Acesso em 30/10/2017.

OLIVEIRA, Regis Fernandes de. Curso de Direito Financeiro. $4^{\mathrm{a}}$ edição. São Paulo: Editora RT, 2011.

ORJUELA ESCOBAR, Luís Javier. El Estado Colombiano en los noventa: entre la legitimidad y la eficiencia. Revista de Estudios Sociales, n. 1. Universidad de Los Andes Bogotá, Colombia, agosto, 1998.

OSTA, Ana; CALDAS, José Castro. A União Europeia e Portugal entre os resgates bancários e a austeridade: um mapa das políticas e das medidas. In A Anatomia da Crise: Relatório do Observatório sobre Crises e Alternativas. Centro de Estudos Sociais. Universidade de Coimbra. Dezembro de 2013.2 Disponível em http://www.ces.uc.pt/ficheiros2/files/Relatorio_Anatomia_Crise_final__pdf\#page=72. Acesso em 05/05/2017.

PACHECO, Cristina Carvalho. Poder judiciário, reformas liberalizantes e construção democrática nos anos 90: alguns prismas desse confronto no ordenamento jurídico brasileiro. Dissertação de Mestrado. IFCH - Unicamp. 2000.

O Supremo Tribunal Federal e a reforma do Estado: uma análise das ações diretas de inconstitucionalidade julgadas no primeiro governo de Fernando Henrique Cardoso (1995-1998). Tese de Doutorado. IFCH-Unicamp, 2006.

PAIVA, Andrea Barreto de; MESQUITA, Ana Cleusa Serra; JACCOUD, Luciana; PASSOS, Luana. O Novo Regime Fiscal e suas implicações para a política de Assistência Social no Brasil. Nota Técnica no 27. Brasília: IPEA, 2016.

PARRISH, Michael E. The Great Depression, the New Deal, and the American Legal Order. Washington Law Review, v. 59, p. 723, 1983. 
PASCUAL, Maribel González. Welfare rights and euro crisis - the Spanish case. In KILPATRICK, Claire; DE WITTE, Bruno (eds.). Social rights in times of crisis in the Eurozone: The role of fundamental rights' challenges. EUI Working Papers LAW 2014/05. Fiesole: European University Institute, 2014.

PASSOS, Antônio de Pádua Ferreira; CASTRO, Priscila de Souza Cavalcante. O Orçamento e a Dívida Pública Federal. Parte 2. Capítulo 4. In SILVA, Anderson Caputo.; CARVALHO, Lena O.; MEDEIROS, Otávio L. (Orgs.). Dívida Pública: a experiência brasileira. Brasília: Secretaria do Tesouro Nacional. 2009.

PAULANI, Leda Maria. Capitalismo financeiro e estado de emergência econômico no Brasil: o abandono da perspectiva do desenvolvimento. In: I Colóquio da Sociedade Latino Americana de Economia Política e Pensamento Crítico. Santiago, 2006.

. Brasil Delivery: servidão financeira e estado de emergência econômico. São Paulo: Boitempo Editorial, 2008.

PAVOLINI, Emmanuele; LEÓN, Margarita; GUILLÉN, Ana, M.; ASCOLI, Ugo. From austerity to permanent strain? The EU and welfare state reform in Italy and Spain. Comparative European Politics, v. 13, n. 1, p. 56-76, 2015.

PEDERIVA, João Henrique; LUSTOSA, Paulo Roberto Barbosa. Créditos Extraordinários e Medidas Provisórias no Brasil: uma Análise Sistêmica. RAC-Eletrônica, v. 1, n. 2, p. 97$113,2007$.

PEDRA, Adriano Sant'Ana. As mutações constitucionais e o limite imposto pelo texto da constituição: uma análise da experiência Latino-americana. Revista Brasileira de Estudos Políticos, v. 101, p. 7-36, 2010.

PÉREZ, José Luis Monereo. Estudio Preliminar - Hermann Heller y la constitución política de la sociedad. In: HELLER, Hermann. Las ideas políticas contemporâneas. Trad. Manuel Pedroso. Granada: Ed. Comares, 2004.

PINTO, Élida Graziane. Financiamento de Direitos Fundamentais: políticas públicas vinculadas, estabilização monetária e conflito distributivo no orçamento da União do pósPlano Real. Belo Horizonte: Editora O Lutador, 2010.

Eficácia dos direitos sociais por meio do controle judicial da legalidade orçamentária e da sua adequada execução. Revista Fórum de Direito Financeiro e Econômico - RFDFE, v. 3, p. 71-100, 2014.

. Novo Regime Fiscal e a mitigação dos pisos de custeio da saúde e educação. Cadernos de Saúde Pública, v. 32, 2016.

Da saúde aos presídios vivemos um Estado de Coisas Inconstitucional. Conjur Contas à vista. Disponível em https://www.conjur.com.br/2017-jan-31/contas-vista-saudeaos-presidios-temos-estado-coisas-inconstitucional. Acesso em 23/10/2017.

Mínimos minorados na iminência do seu congelamento por 20 anos. Conjur - Contas à vista. Disponível em http://www.conjur.com.br/2017-abr-25/contas-vista-minimosminorados-iminencia-congelamento-20-anos. Acesso em 26/05/2017. 
STF reconhece o direito de ter o custeio adequado dos direitos. Conjur - Contas à vista. Disponível em https://www.conjur.com.br/2017-set-12/contas-vista-stf-reconhecedireito-custeio-adequado-direitos-adi-5595. Acesso em 23/10/2017.

; DE MORAES BAHIA, Alexandre Melo Franco; SANTOS, Lenir. O financiamento da saúde na Constituição de 1988: um estudo em busca da efetividade do direito fundamental por meio da equalização federativa do dever do seu custeio mínimo. A\&C Revista de Direito Administrativo \& Constitucional, v. 16, n. 66, p. 209-237, 2017.

PINTO, Felipe Chiarello de Souza; DONADELLI, Antonio Paulo de Mattos. O papel do Judiciário, o Estado de Direito e o chamado ativismo judicial na doutrina brasileira. Revista Novos Estudos Jurídicos, v. 19, n. 1, p. 42-76, 2017.

; DOS SANTOS, Larissa Dias Puerta. A atuação estatal desempenhada para fomentar o desenvolvimento brasileiro. Revista Justiça do Direito, v. 31, n. 1, p. 170-187, 2017.

PISARELLO, Geraldo. Um largo termidor: Historia y critica del constitucionalismo antidemocrático. Quito: Corte Constitucional del Ecuador, 2011.

. El constitucionalismo social ante la crisis: entre la agonía y la refundación republicano-democrática. Revista Derecho del Estado, nº 28, 2012.

POLANYI, Karl. La gran transformación. Critica del liberalismo económico. Ediciones de La Piqueta. Madrid. Tradução livre. 1989.

QUADRA-SALCEDO FERNÁNDEZ DEL CASTILLO, Tomás de la. Derecho Público tras la crisis económica en el Estado social y democrático: Estado de bienestar y servicios de interés general. In: Crisis y Constitución - XIX Jornadas de la Asociación de Letrados del Tribunal Constitucional. Madrid: Associación de Letrados del Tribunal Constitucional/ Centro de Estudios Politicos y Constitucionales, 2015.

REYNOLDS, John. The Political Economy of States of Emergency. Oregon Review of International Law. June 30, 2012.

RODRÍGUEZ, Pablo Martín. A Missing Piece of European Emergency Law: Legal Certainty and Individuals' Expectations in the EU Response to the Crisis. European Constitutional Law Review, v. 12, n. 02, p. 265-293, 2016.

ROJAS, Francisco José Villar. El control de la estabilidad presupuestaria local: de nuevo la tutela estatal y sus vicios. In LEÓN, José Maria Baño. Memorial para la reforma del Estado: Estudios en homenaje al Profesor Santiago Muñoz Machado. 2016.

ROSSI, Pedro; DWECK, Esther. Impactos do novo regime fiscal na saúde e educação. Cad. Saúde Pública, Rio de Janeiro, v. 32, n. 12, 2016.

RUIZ ALMENDRAL, Violeta. Estabilidad presupuestaria y gasto público en España. Madrid: La Ley, 2008.

Estabilidad Presupuestaria y Reforma Constitucional (Fiscal Compact and Constitutional Reform in Spain). REDE $n^{o}$ 41. Enero-Marzo -2012. 
. La nueva Ley de Estabilidad Presupuestaria y Sostenibilidad Financiera. Revista Española de Control Externo, vol. 14, n. 41. 2012.

. Curbing the Deficit in Spain and its Autonomous Communities: a Constitutional Conundrum. Center for Constitutional Studies, Madrid, October, 2012.

. La estabilidad presupuestaria en la Constitución española. In: V Giornate italoispano-brasiliane di diritto costituzionale: "La Costituzione alla prova della crisi finanziaria mondiale”, 2012. Disponível em http://www.gruppodipisa.it/wpcontent/uploads/2012/09/Violeta.pdf. Acesso em 05/08/2015.

. A Myopic Economic Constitution? Controlling the Debt and the Deficit without Fiscal Integration. EUI Department of Law Research Paper No. 2015/12. Disponível em http://eurocrisislaw.eui.eu/wp-content/uploads/2015/05/Law_2015_12.pdf. Acesso em 20/01/2016.

; CUENCA, Alain. Reforma de la Constitución y del modelo de federalismo fiscal en España. In RUSSO, Anna Margherita (ed.). Los escenarios móviles del derecho regional europeo. Reflexionando en el palácio de Godoy. Centro de Estudios Políticos y Constitucionales: Madrid, 2015.

SABBAG. Cesar de Moraes. Breves Considerações sobre deficiências estruturais do sistema orçamentário brasileiro. In CONTI, José Maurício; SCAFF, Fernando Facury (coord.). Orçamentos Públicos e Direito Financeiro. São Paulo: Editora Revista dos Tribunais, 2011.

SALAZAR BENÍTEZ, O. La Constitución domesticada: algunas reflexiones críticas sobre la reforma del art. 135 de la Constitución. Teoría y Realidad Constitucional, n. 29. UNED, 2012.

SALES, Pedro Henrique Ramos. PLS 204/16 e o mito da securitização da dívida pública: um mau negócio à vista. In JOTA. Disponível em https://goo.gl/KJ5Vmx. Acesso em 29/10/2016.

SALOMON, Margot E. Of Austerity, Human Rights and International Institutions. European Law Journal, Vol. 21, nº 4, pp. 521-545, July 2015.

SANTISO, Carlos. Judicial governance in Brazil. In GLOPPEN, Siri et al. (eds). Democratization and the Judiciary. London: Frank Cass, 2004.

SARMENTO, Joaquim Miranda. A reforma da Lei de Enquadramento Orçamental. Revista JULGAR - online. Setembro de 2015. Disponível em http://julgar.pt/a-reforma-da-lei-deenquadramento-orcamental/. Acesso em 23/03/2017.

SCAFF, Fernando Facury. Ensaio sobre o conteúdo jurídico do princípio da lucratividade. In: Antonio G. Maués (org.). Constituição e Democracia. $1^{\text {a }}$ ed. São Paulo: Max Limonad, 2001.

Constituição Econômica Brasileira em seus 15 anos. Revista de Direito Público da Economia - RDPE, Belo Horizonte, v. 3, jul/set, 2003.

Direitos Humanos e a Desvinculação das Receitas da União - DRU. In: Octávio Campos Fischer. (Org.). Tributos e Direitos fundamentais. $1^{\mathrm{a}}$ ed. São Paulo: Dialética, 2004. 
O Jardim e a Praça ou a Dignidade Humana e o Direito Tributário e Financeiro. In: Heleno Taveira Tôrres. (Org.). Direito e Poder - Nas Instituições do Público e do Privado Contemporâneos - Estudos em Homenagem a Nelson Saldanha. São Paulo: Manole, 2005.

. Como a Sociedade Financia o Estado para a Implementação dos Direitos Humanos? In COUTINHO, Jacinto Nelson de Miranda; MORAIS, Jose Luis Bolzan de; STRECK, Lenio Luiz. (Org.). Estudos Constitucionais. São Paulo: Renovar, v. 1, 2007.

; ANDRADE, César Augusto Seijas de. A dívida pública com precatórios após 10 anos da LRF ou como a Resolução no 40/2001 caloteou a República. In SCAFF, Fernando Facury; CONTI, José Maurício (Orgs.). Lei de Responsabilidade Fiscal - 10 anos de vigência. Florianópolis: Conceito Editorial, 2010.

Direito à saúde e os tribunais. In: NUNES, António José Avelãs; SCAFF, Fernando Facury. Os tribunais e o direito à saúde. Porto Alegre: Editora Livraria do Advogado, 2011.

Recuperação de créditos acumulados de ICMS na exportação. In: ROCHA, Valdir de Oliveira (Coord.). Grandes questões atuais de direito tributário. São Paulo: Dialética, v. 16, p. 52-74. 2012.

Royalties do petróleo, minério e Energia: aspectos constitucionais, financeiros e tributário. São Paulo: Editora Revista dos Tribunais. 2014.

Dívida Pública atrasa ampliação de Direitos Fundamentais e Investimento Público. Conjur - Contas a vista. 2014. Disponível em http://www.conjur.com.br/2014-set09/contas-vista-divida-publica-atrasa-ampliacao-direitos-fundamentais. Acesso em 22/05/2017.

Crédito Público e sustentabilidade financeira. Revista Direito à Sustentabilidade. Universidade Estadual do Oeste do Paraná, Campus Foz do Iguaçu. Centro de Ciências Sociais aplicadas, v. 01, n.1. For do Iguaçu: Triunfal Gráfica e Editora, 2014.

Magna Carta e Bill of Rights: entre o Direito Financeiro e o Direito Tributário. In Conjur - Contas à Vista. 2015 Disponível em https://www.conjur.com.br/2015-jun16/contas-vista-magna-carta-bill-of-rights-entre-direito-financeiro-tributario. Acesso em 20/11/2017.

. Surge o orçamento impositivo à brasileira pela Emenda Constitucional. Conjur Contas à vista. 2015. Disponível em <https://goo.gl/vXU3hz> . Acesso em 24/05/2017.

As agruras do homem no estado endividado. Prefácio. In NUNES, António José Avelãs. Quo Vadis, Europa? São Paulo: Editora Contracorrete, 2016.

; ATHIAS, Daniel Tobias. Dívida Pública e Desenvolvimento: do equilíbrio orçamentário à sustentabilidade financeira. Revista Científica FAGOC-Jurídica, v. 1, n. 1, p. 85-96, 2016.

Primeiro dever fundamental do Supremo Tribunal Federal é dizer não. Conjur Contas à vista. 2016. Disponível em https://goo.gl/LdA26C. Acesso em 28/10/2017. 
. Emenda Orçamentária 86/2015 foi declarada inconstitucional. Conjur - Contas à vista. 2017. Disponível em https://www.conjur.com.br/2017-set-05/contas-vista-emendaorcamentaria-86-foi-declarada-inconstitucional-dai. Acesso em 23/10/2017.

. Orçamento Republicano e Liberdade Igual: Direito Financeiro, República e Direitos Fundamentais. Tese para o concurso de Professor Titular da Faculdade de Direito Universidade de São Paulo. São Paulo: USP, 2017.

SCHACHT, Hjalmar. Setenta e seis anos de minha vida: a autobiografia do mago da economia alemã da República de Weimar ao III Reich. São Paulo: Ed. 34, 1999.

SCHEUERMAN, William E. Carl Schmitt: the end of law. Oxford: Rowman \& Littlefield, 1999.

. The Economic State of Emergency, Cardozo Law Review. Vol. 21. Yeshiva University, 2000.

Survey Article: Emergency Powers and the Rule of Law After 9/11. In the Journal of Political Philosophy: Volume 14, Number 1, 2006.

SCHILLER, Reuel E. The Era of Deference: Courts, Expertise, and the Emergence of New Deal Administrative Law. Michigan Law Review, p. 399-441, 2007.

SCHMITT, Carl. O conceito do político. Apresentação de Hans Georg Flickinger. Trad. De Alvaro L. M. Valls. Petrópolis: Vozes, 1992.

. La defensa de la Constitución. Madrid: Editora Tecnos, 1998.

. Sobre os três tipos do pensamento jurídico. Tradução de Peter Naumann. Revisão de Ronaldo Porto Macedo Jr. In MACEDO JR.; Ronaldo Porto. Carl Schmitt e a fundamentação do direito. São Paulo: Max Limonad, 2001.

. Teologia política. Trad. Francisco Javier Conde; Jorge Navarro Perez. Madrid: Editorial Trotta, 2009.

SERRANO, Pedro Estevam Alves Pinto. Autoritarismo e golpes na América Latina: breve ensaio sobre jurisdição e exceção. São Paulo: Almedina, 2016.

SILVA, Maria Viegas. O Judiciário brasileiro e a falta de independência dos juízes como um relexo do sistema judicial no Brasil. In LIMA JR., Jayme Benvenuto (org.). Independência dos juizes: aspectos relevantes, casos e recomendações. Recife: Gajop; Bagaço, 2005.

SILVA, Sandoval Alves da. O Ministério Público e a concretização dos direitos humanos. Salvador: Juspodium, 2016.

SILVEIRA, Alexandre Coutinho da. Orçamento e Planejamento: tensões entre os poderes. Revista Fórum de Direito Financeiro e Econônico - RFDFE, ano 4, n. 6. Belo Horizonte, p. 31-58, 2015.

SILVEIRA, Francisco Secaf Alves. A concretização do Direito Financeiro: os efeitos do contingenciamento na execução orçamentária. Dissertação de Mestrado. Faculdade de Direito da Universidade de São Paulo. 2014. 
Problemas e Diagnósticos na Execução do Planejamento Orçamentário. Revista Fórum de Direito Financeiro e Econônico - RFDFE, ano 4, n. 6. Belo Horizonte, p. 59-78, 2015.

SIQUEIRA NETO, José Francisco. Golpe Militar e Desenvolvimento Econômico. In: Lima, Martonio Mont'Alverne Barreto; Carmo, Valter Moura do; Coutinho, Júlia Maia de Meneses. (Orgs.). Progresso e regresso político: a democracia em risco. Rio de Janeiro: Editora Lumen Juris, 2017.

SOARES, António Goucha. A reforma da governação económica da UE: O colete de regras europeias. Relações Internacionais, n. 48, pp. 79-97. Lisboa, dez. de 2015.

STOLLEIS, Michael. Judicial review, administrative review, and constitutional review in the Weimar Republic. Ratio Juris, v. 16, n. 2, p. 266-280, 2003.

STRECK, Lenio Luiz; LIMA, Martonio Mont'Alverne Barreto; DE OLIVEIRA, Marcelo Andrade Cattoni. A Nova Perspectiva do Supremo Tribunal Federal sobre o Controle Difuso: Mutação constitucional e Limites da Legitimidade da Jurisdição Constitucional. Argumenta Journal Law, v. 7, n. 7, p. 45-68, 2007.

O que é preciso para (não) se conseguir um Habeas Corpus no Brasil. Conjur. Disponível em https://www.conjur.com.br/2015-set-24/senso-incomum-preciso-nao-obterhc-brasil. Acesso em 23/10/2017.

STREECK, Wolfgang. As crises do capitalismo democrático. Novos estud. - CEBRAP, São Paulo, n. 92, p. 35-56, Mar. 2012.

Tempo comprado: a crise adiada do capitalismo democrático. Trad. Marian Toldy e Teresa Toldy. Lisboa: Actual editora, 2012.

STURM, Roland. El federalismo en Alemania hoy. In HOFMEISTER, Wilhelm; ARANDA, José Tudela (editores). Sistemas Federales: una comparación internacional. Fundación Konrad Adenauer/ Fundación Manuel Giménez Abad. España, 2017.

SUNSTEIN, Cass R. Constitutionalism after the new deal. Harvard Law Review, vol. 101, pp. 421-510, 1987.

TANNO, Claudio Riyudi. Novo regime fiscal constante da pec $n^{o}$ 241/2016: análise dos Impactos nas políticas educacionais. Estudo Técnico $\mathrm{n}^{\circ} 18$, de agosto de 2016. Câmara dos Deputados. Consultoria de Orçamento e Fiscalização Financeira. 2016.

TATE, Neal e VALLINDER, Torbjorn (eds.). The Global Expansion of Judicial Power. New York: New York University Press, 1995.

TEGA, Diletta. Welfare Rights in Italy. In KILPATRICK, Claire; DE WITTE, Bruno (eds.). Social rights in times of crisis in the Eurozone: The role of fundamental rights' challenges. EUI Working Papers LAW 2014/05. Fiesole: European University Institute, 2014.

TORRES, Heleno Taveira. Direito Constitucional Financeiro: Teoria da Constituição Financeira. São Paulo: Editora Revista dos Tribunais, 2014. 
Reformas

do

federalismo

fiscal

avançam no Brasil. Conjur - Consultor Jurídico. Disponível em http://www.conjur.com.br/2015-ago-12/consultor-tributario-reformas-federalismo-fiscalavancam-brasil\#_ftnref1. Acesso em 27/11/2015).

TORRES, Ricardo Lobo. Curso de direito financeiro e tributário. $16^{\mathrm{a}}$ ed. São Paulo: Renovar, 2009.

TUORI, Kaarlo; TUORI, Klaus. The Eurozone crisis: a constitutional analysis. Cambridge University Press, 2014.

TUSHNET, Mark. The political constitution of emergency powers: parliamentary and separation-of-powers regulation. International Journal of Law in Context, v. 3, n. 04, pp. 275-288, 2007.

Emergencias y la idea de Constitucionalism. In TUSHNET, Mark. Constitucionalism y Judicial Review (org. por Pedro Grández Castro). Lima: Palestra Editores, 2013.

UPRIMNY, Rodrigo. The Constitutional Court and Control of Presidential Extraordinary Powers in Colombia. In GLOPPEN, Siri; GARGARELLA, Roberto; SKAAR, Elin (eds). Democratization and the Judiciary. London: Frank Cass, 2004.

VARGAS, Neide César. A descentralização e as teorias do Federalismo Fiscal. Ensaios FEE, Porto Alegre: v. 32, p. 60. 2011.

VERBICARO, Loiane Prado. Um estudo sobre as condições facilitadoras da judicialização da política no Brasil. Revista Direito GV, v. 4, n. 2, pp. 389-406, 2008.

VESELY, Thiago Andrigo. Emendas orçamentárias como instrumento de coordenação no legislativo brasileiro. Monografia apresentada ao Programa de Pós-Graduação do Centro de Formação, Treinamento e Aperfeiçoamento da Câmara dos Deputados/CEFOR. Brasília, 2012.

VIANNA, Luiz Werneck et alii. A judicialização da política e das relações sociais no Brasil. Rio de Janeiro: Editora Revan, 1999.

VIEIRA, Fabiola Sulpino; SÁ E BENEVIDES, Rodrigo Pucci de. Os impactos do novo regime fiscal para o financiamento do Sistema Único de Saúde e para a efetivação do direito à saúde no Brasil. Nota Ténica n. 28. Brasília: IPEA, 2016.

VITA, Leticia. La noción de principios jurídicos en la teoría del derecho de Hermann Heller. Isonomía, n. 43, pp. 49-75, 2015.

VÍTOLO, Alfredo. Emergencias Constitucionales I: estado de sitio. $1^{\mathrm{a}}$ ed. Buenos Aires/Madrid: Ciudad Argentina, 2004.

ZIZEK, Slavoj. A Permanent Economic Emergency. New Left Review 64. July/aug, 2010. Disponível em https://newleftreview.org/II/64/slavoj-zizek-a-permanent-economicemergency. Acesso em 15/05/2016. 


\section{Documentos oficiais, decisões e legislação}

ARGENTINA. Corte Suprema de Justicia de la Nación. Fallo Peralta. Julgado em 27/12/1990. . Corte Suprema de Justicia de la Nación. Fallo Cocchia. Julgado em 02/12/1993. . Corte Suprema de Justicia de la Nación. Fallo Burgos. Julgado em 26/10/2004.

Corte Suprema de Justicia de La Nación. Emergencia económica II: Secretaría de Jurisprudencia. Buenos Aires: Corte Suprema de Justicia de la Nación, 2009.

Tribunal de Contas da União. Pleno. Acórdão n 287/2016. Processo 017.019/2014-1. Relator José Múcio Monteiro. Julgamento em 17/02/2016.

Câmara dos Deputados. Assembleia Nacional Constituinte. Ata de Comissões. Subcomissão de orçamento e Fiscalização Financeira. $5^{\text {a }}$ Reunião. 05/05/1987. Audiência Pública - Sistema de planejamento e orçamento - Expositor: Nilson Holanda Diário da Assembleia Nacional Constituinte de 19/06/1987. Suplemento 80, p. 153. Disponível em https://goo.gl/BGSyPD. Acesso em 22/05/2017.

Câmara dos Deputados. Comissão de Sistematização III. Diário da Assembleia Nacional Constituinte (Suplemento "C"). Disponível em https://goo.gl/FbGe7L. Acesso em 20/05/2017.)

. Câmara dos Deputados. CPI da Dívida Pública. Relatório Final. Relator Deputado Pedro Novais. Maio de 2010. Disponível em https://goo.gl/jwnP3p. Acesso em 10/10/2017.

Câmara dos Deputados. Despacho 04/05 3A do Poder Legislativo. Sugestão: 02097 DT REC: 29/04/87. Autoria do Constituinte Gerson Câmara (PMDB/ES). Disponível em http://www6g.senado.gov.br/apem/data/SGCO/2093.html. Acesso em 21/05/2017.

. Câmara dos Deputados. Exposição de motivos da PEC 241/2016. Disponível em $<$ http://www.camara.gov.br/proposicoesWeb/prop_mostrarintegra?codteor=1468431\&filen ame=PEC+241/2016> . Acesso em 28/03/2017.

Câmara dos Deputados. Exposição de motivos da PEC 241/2016. Disponível em http://www.camara.gov.br/proposicoesWeb/prop_mostrarintegra?codteor=1468431\&filena me=PEC+241/2016. Acesso em 28/03/2017.

Câmara dos Deputados. PEC 4/2015. Exposição de motivos. Disponível em http://www.camara.gov.br/proposicoesWeb/fichadetramitacao?idProposicao=946734. Acesso em 18/10/2017.

Câmara dos Deputados. PLP no 257/16. Exposição de motivos. Disponível em http://www.camara.gov.br/proposicoesWeb/fichadetramitacao?idProposicao=2080237. Acesso em 05/12/2017.

Câmara dos Deputados. PLP no 343/2017. Exposição de motivos. Disponível em http://www.camara.gov.br/proposicoesWeb/fichadetramitacao?idProposicao=2124451. Acesso em 15/11/2017. 
Câmara dos Deputados. Proposta de Emenda à Constituição no 550/2006. Disponível em http://www.camara.gov.br/proposicoesWeb/fichadetramitacao?idProposicao=326652. Acesso em 20/11/2017.

. CNJ. Relatório Precatórios. Reestruturação da Gestão dos Tribunais. Disponível em http://www.cnj.jus.br/images/imprensa/precatorios/realtorio_precatorios_CNJ_FINAL1.pd f. Acesso em 02/11/2017.

Ministério do Planejamento, Orçamento e Gestão. Glossário. Contingenciamento. Disponível em http://www.orcamentofederal.gov.br/glossario. Acesso em 22/11/2015.

. PGFN. PGFN em números. Edição 2017. Disponível em http://www.fazenda.gov.br/noticias/2017/fevereiro/pgfn-disponibiliza-edicao-2017-do201cpgfn-em-numeros201d/201cpgfn-em-numeros201d-2017.pdf. Acesso em 04/11/2017.

Procuradoria Geral da Fazenda Nacional. Parecer PGFN/CAF nº 1579/2014.

Secretaria de Orçamento Federal. Vinculações de Receitas dos Orçamentos Fiscal e da Seguridade Social e o Poder Discricionário de Alocação dos Recursos do Governo Federal - Volume 1, n. 1 (2003) - Brasília. Secretaria de Orçamento Federal - SOF.

Secretaria do Tesouro Nacional. Metodologia de Cálculo do Superávit Primário. Disponível em http://www3.tesouro.fazenda.gov.br/hp/downloads/resultado/mnf_gv_central.pdf. Acesso em 31/05/2014.

. Senado Federal. Instituição Fiscal Independente. Relatório de Acompanhamento Fiscal. Junho de 2017. Disponível em https://goo.gl/HCYk37. Acesso em 26/07/2017.

. Senado Federal. Parecer da Comissão de Assuntos Econômicos ao PLS nº 204/2016. Disponível em http://legis.senado.leg.br/sdleggetter/documento?dm=4160898\&disposition=inline. Acesso em 01/11/2017.

Senado Federal. PLS $n^{\circ}$ 204/2016. Disponível em https://www25.senado.leg.br/web/atividade/materias/-/materia/125723. Acesso em 01/11/2017. O projeto foi inicialmente aprovado pelo Senado em 13/12/2017.

. Senado Federal. Projeto de Resolução do Senado $n^{\circ}$ 50/2015 (convertido na Resolução $\mathrm{n}^{\mathrm{o}}$ 17/2015). Disponível em http://legis.senado.leg.br/sdleggetter/documento?dm=3012410\&disposition=inline. Acesso em 06/11/2015.

. Senado Federal. Proposta de Emenda à Constituição nº 45, de 2008. Disponível em http://www25.senado.leg.br/web/atividade/materias/-/materia/88675. Acesso em 20/11/2017.

Decisão Monocrática. ADI no 5.072. Medida Cautelar. Ministro Gilmar Mendes. Decisão em 14/02/2017.

Supremo Tribunal Federal. Pleno. ADI 4.357. Relator Ministro Ayres Britto. Relator para acórdão Ministro Luiz Fux. Julgado em 14/03/2013. 
. Supremo Tribunal Federal. Pleno. ADI 4.425. Questão de Ordem. Relator Ministro Luiz Fux. Julgado em 25/03/2015.

. Supremo Tribunal Federal. Ação Direta de Inconstitucionalidade $n^{\circ}$ 5.658. Inicial.

. Supremo Tribunal Federal. ADI 2.010/MC. Relator Ministro Celso de Mello. Julgado em 30/09/1999.

Supremo Tribunal Federal. ADI n ${ }^{0}$ 5.595. Decisão Monocrática. Ministro Ricardo Lewandowski. Julgado em 27/09/2017.

Supremo Tribunal Federal. ADPF n ${ }^{\circ}$ 45. Decisão Monocrática. Ministro Celso de Mello. Julgado em 29/04/2004.

. Supremo Tribunal Federal. Decisão monocrática. Mandado de Segurança $\mathrm{n}^{\circ}$ 34.448/MC/DF, Relator Ministro Roberto Barroso. Julgado em 10/10/2016.

. Supremo Tribunal Federal. Pleno. ADI 1640 QO. Relator Ministro Sydney Sanches. Julgamento em 12/02/1998.

. Supremo Tribunal Federal. Pleno. ADI 2.925/DF. Relatora Ministra Ellen Gracie. Relator para acórdão Ministro Marco Aurélio. Julgamento 19/12/2003.

. Supremo Tribunal Federal. Pleno. ADI 4.048/DF. Relator Ministro Gilmar Mendes. Julgamento em 14/05/2008.

. Supremo Tribunal Federal. Pleno. ADI 4.365/DF. Relatora Ministro Dias Toffoli. Julgamento em 05/03/2015.

. Supremo Tribunal Federal. Pleno. ADPF n 347/MC. Relator Ministro Marco Aurélio. Julgado em 09/09/2015.

. Supremo Tribunal Federal. Pleno. Reclamação no 4.335/AC. Voto-vista do Ministro Eros Grau. Proferido em julgamento de 01/02/2007.

. Supremo Tribunal Federal. Recurso Extraordinário n ${ }^{\circ}$ 592.581/RS. Relator Ministro Ricardo Lewandowski. Julgado em 13/08/2015.

. Supremo Tribunal Federal. Repercussão Geral. Tema 220. Leading case: Recurso Extraordinário $\mathrm{n}^{\circ}$ 592.581/RS. Relator Ministro Ricardo Lewandowski. Julgado em $13 / 08 / 2015$.

. Supremo Tribunal Federal. Segunda Turma. Habeas Corpus $\mathrm{n}^{\circ}$ 91.361. Relator Ministro Celso de Mello. Julgado em 23/09/2008.

. Supremo Tribunal Federal. Pleno. ADI 4.048/DF. Relatora Ministro Gilmar Mendes. Julgamento em 14/05/2008.

Supremo Tribunal Federal. Segunda Turma. ADI 1.717/MC, Relator Ministro Sydney Sanches, julgado em 22-9-1999. STF. Pleno. RE 592377, Relator Ministro Marco Aurélio, Relator p/ Acórdão Ministro Teori Zavascki, julgado em 04/02/2015. 
. Supremo Tribunal Federal. A Constituição e o Supremo - artigo 102, caput, CF. ADI 3.345, Relator Ministro Celso de Mello, julgado em 25/08/2005. Disponível em http://www.stf.jus.br/portal/constituicao/artigoBd.asp?item=1079. Acesso em 04/10/2017.

. Supremo Tribunal Federal. Pleno. ADI 1753/MC, Relator Ministro Sepúvelda Pertence, julgado em 16/04/1998).

. Supremo Tribunal Federal. Pleno. ADI 2213/MC, Relator Ministro Celso de Mello, julgado em 04/04/2002.

. Supremo Tribunal Federal. Pleno. ADI 534. Relator Ministro Celso de Mello. Medida cautelar julgada em 27/06/1991 e questão de ordem julgada em 26/08/1992.

. Supremo Tribunal Federal. Pleno. ADI 939. Relator Ministro Sydney Sanches, julgado em 15/12/1993.

Supremo Tribunal Federal. Pleno. RE 150764. Relator Ministro Sepúvelda Pertence. Relator p/ Acórdão Ministro Marco Aurélio, julgado em 16/12/1992.

. Tribunal de Contas da União. Pleno. Acórdão 772/2016. Processo 016.585/2009. Julgado em 06/04/2016.

. Tribunal de Contas da União. Pleno. TC 012.659/2017-7. Tomada de contas Presidência. Julgado em 28/06/2017.

. Tribunal de Contas da União. Processo 016.585/2009.

. Tribunal de Contas da União. Processo TC 043.416/2012-8.

. Tribunal de Contas da União. TC 012.659/2017-7. Relatório e Pareceres prévios sobre as Contas da Presidência da República. 2016.

Tribunal de Contas do Estado de São Paulo. Manual. O Tribunal e a Gestão Financeira dos Prefeitos. Fevereiro, 2012.

EUROPA. Parlamento Europeu. Fichas Técnicas sobre a União Europeia. O quadro da UE para políticas orçamentais. Disponível em http://www.europarl.europa.eu/atyourservice/pt/displayFtu.html?ftuId=FTU_4.2.1.html. Acesso em 19/05/2017.

EUROPEAN COMISSION. The Fiscal Compact - Taking Stock. Disponível em https://ec.europa.eu/info/publications/fiscal-compact-taking-stock_en. Acesso em 13/06/2017.

EUR-LEX. Glossário. Pacto de Estabilidade e Crescimento. Disponível em http://eurlex.europa.eu/summary/glossary/stability_growth_pact.html?locale=pt. Acesso em 05/05/2017.

PIAUÍ. Tribunal de Contas. Nota Técnica no 001/2017. Disponível em https://www.tce.pi.gov.br/wp-content/uploads/2017/01/NOTA-TÉCNICA_DECRETODE-EMERGÊNCIA.pdf. Acesso em 24/05/2017. 
RIO DE JANEIRO. Ministério Público Estadual. Ação Civil Pública n ${ }^{\circ}$ 029733452.2017.8.19.0001. Petição Inicial.

SÃO PAULO. Tribunal de Contas do Estado de São Paulo. Comunicado SDG nº 06/2017. Disponível em https://www4.tce.sp.gov.br/6524-comunicado-sdg-062017-alerta-sobredecretos-calamidade-financeira. Acesso em 24/05/2017. 